\title{
EfFects of Social Security Reform on Private and National Saving
}

\author{
Eric M. Engen and William G. Gale*
}

Social Security is the largest federal government spending program and one of the most popular. ${ }^{1}$ The earmarked payroll taxes that finance Social Security currently exceed benefit payments. By the end of 1996, the Social Security trust fund had accumulated about $\$ 566$ billion in assets and was expected to grow to over $\$ 1.2$ trillion by 2010 . However, longer-term projections suggest that Social Security will face financial shortfalls.

Using intermediate assumptions, the Social Security Trustees' Report (1997) projects that benefit payments will exceed program revenue (payroll tax receipts plus interest income) beginning in 2019. Trust fund balances will then start to decline as reserves are liquidated in order to meet the payments due. In the absence of programmatic changes, full benefits will not be paid on time beginning in 2029. The actuarial deficit over the prescribed 75-year projection period is estimated to be 0.84 percent of GDP; this represents a combination of surpluses in early years

*Senior Economist, Board of Governors of the Federal Reserve System, and Senior Fellow and Joseph A. Pechman Fellow, The Brookings Institution, respectively. The authors thank Henry Aaron, Barry Bosworth, Gary Burtless, Jim Poterba, Andrew Samwick, and conference participants for helpful comments and Stacie Carney for outstanding research assistance. Gale thanks the National Institute on Aging for financial support. The opinions expressed in this paper are those of the authors and do not necessarily reflect the views of the Board of Governors of the Federal Reserve System or other members of its staff, or the officers or staff of The Brookings Institution.

${ }^{1}$ In recent years, Social Security has accounted for almost 23 percent of total federal outlays. A survey for the Employee Benefits Research Council in 1992 revealed that 38 percent of respondents thought Social Security was "one of the most important programs" and another 50 percent cited it as an "important program" (Baggette, Shapiro, and Jacobs 1995). 
and deficits in subsequent years. ${ }^{2}$ No official estimate of the actuarial deficit beyond the 75-year horizon has been made, and certainly major uncertainties accompany any distant forecasts, but it appears likely that the system will continue to fall further out of balance.

These financial difficulties are due primarily to expected demographic trends. The baby-boom generation will begin to retire around 2010. The top panel of Figure 1 shows that the proportion of the elderly relative to the working-age population will increase rapidly as baby boomers make the transition from being workers to Social Security recipients. Even beyond the baby boom generation, the further gradual aging of the American population will continue to exert financial pressure on the system. This is primarily the consequence of projected increases in lifespan (shown in the middle panel), concurrent with relatively constant fertility rates (shown in the bottom panel). These long-term financial problems have spawned significant interest in Social Security reform.

Another factor motivating Social Security reform is the widely held goal of raising national saving. National saving - the sum of saving by households, businesses, and government-is used to finance private and public investment and is a crucial ingredient in raising future living standards. To the extent that investment is undertaken domestically, it can raise the U.S. capital stock and hence the productivity of American workers, which in turn will raise their wages. Saving that finances investment either domestically or abroad will raise the wealth of American households. Raising future living standards, though, requires an increase in national, rather than just private, saving. Public policy changes that raise private saving at the expense of government saving do not add to the pool of funds available for investment; although such changes raise private wealth, they also increase government indebtedness by the same amount.

National saving in the United States fell in the 1980s and, while it has increased in the 1990s, remains low by historical standards. The top panel of Figure 2 shows that net national saving currently is around 6 percent, well below its average since 1950. While this is partially a consequence of the large deficits run by the federal government since the early 1980s, the bottom two panels of Figure 2 show that both private and personal saving rates currently are also below their long-term averages. This long-term stagnation in national and private saving is particularly vexing because it has occurred despite numerous government efforts to raise private saving

2 According to the Trustees' Report, the 75-year deficit could be eliminated with an immediate and permanent 18 percent increase in payroll taxes (from 12.4 percent to 14.6 percent) or an immediate and permanent 15 percent reduction in benefits. 
Figure 1

\section{U.S. Demographics}

Elderly (Age 65 and Over) as Percent of

Percent Working-Age Population (Ages 20 to 64)

50
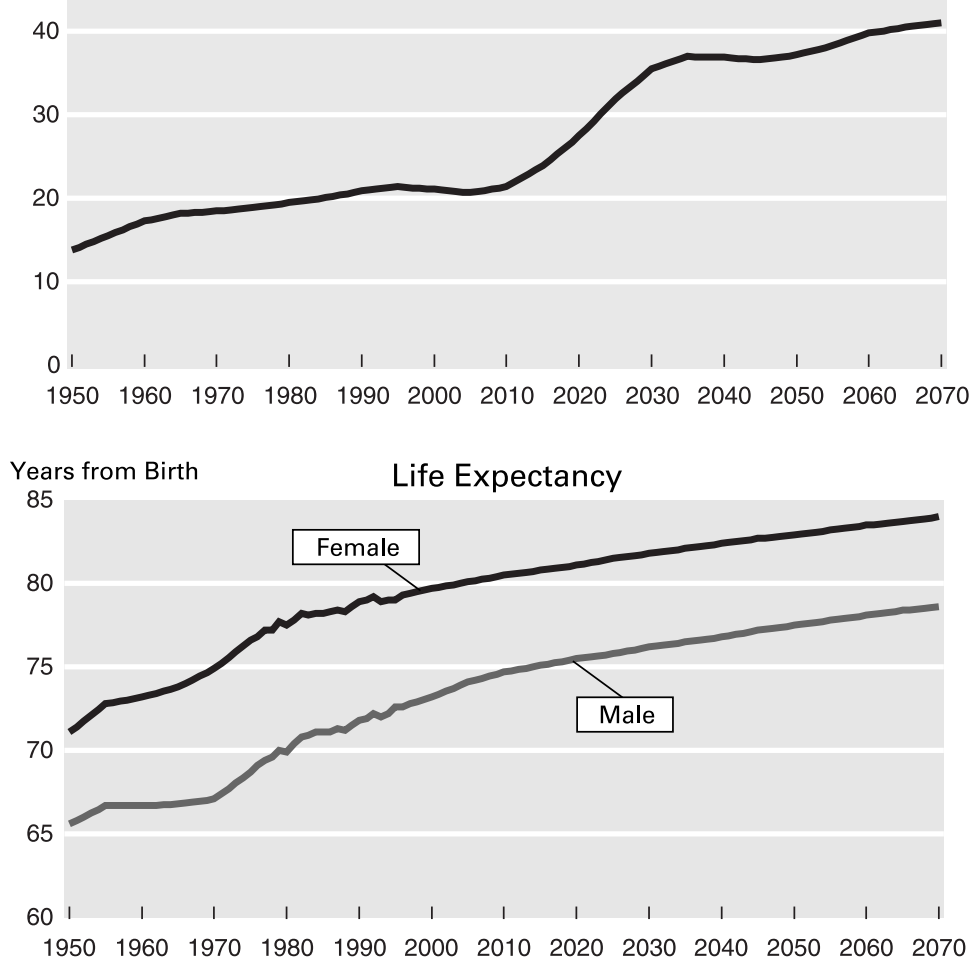

Average Number of Children per Woman (Lifetime)

Fertility Rate

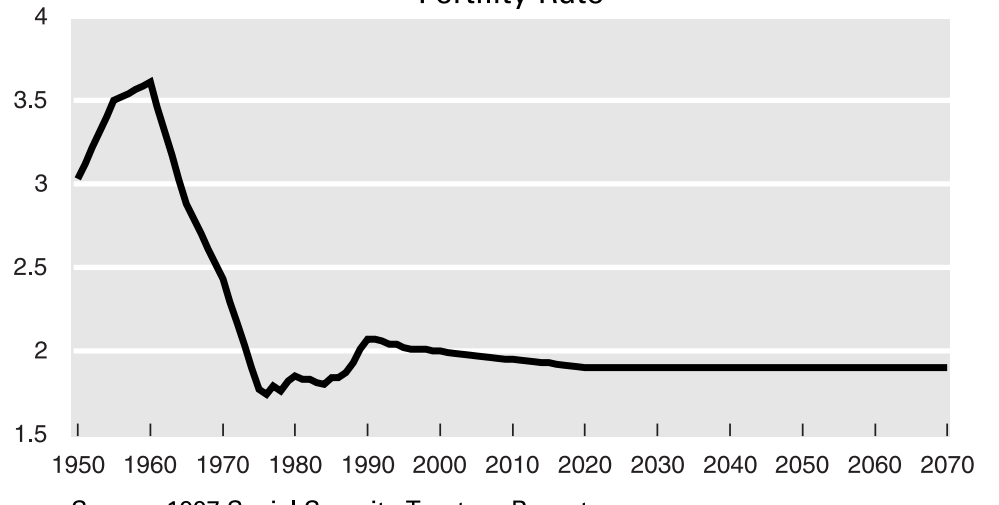

Source: 1997 Social Security Trustees Report. 
Figure 2

U.S. Saving Rates as a Percent of Net National Product
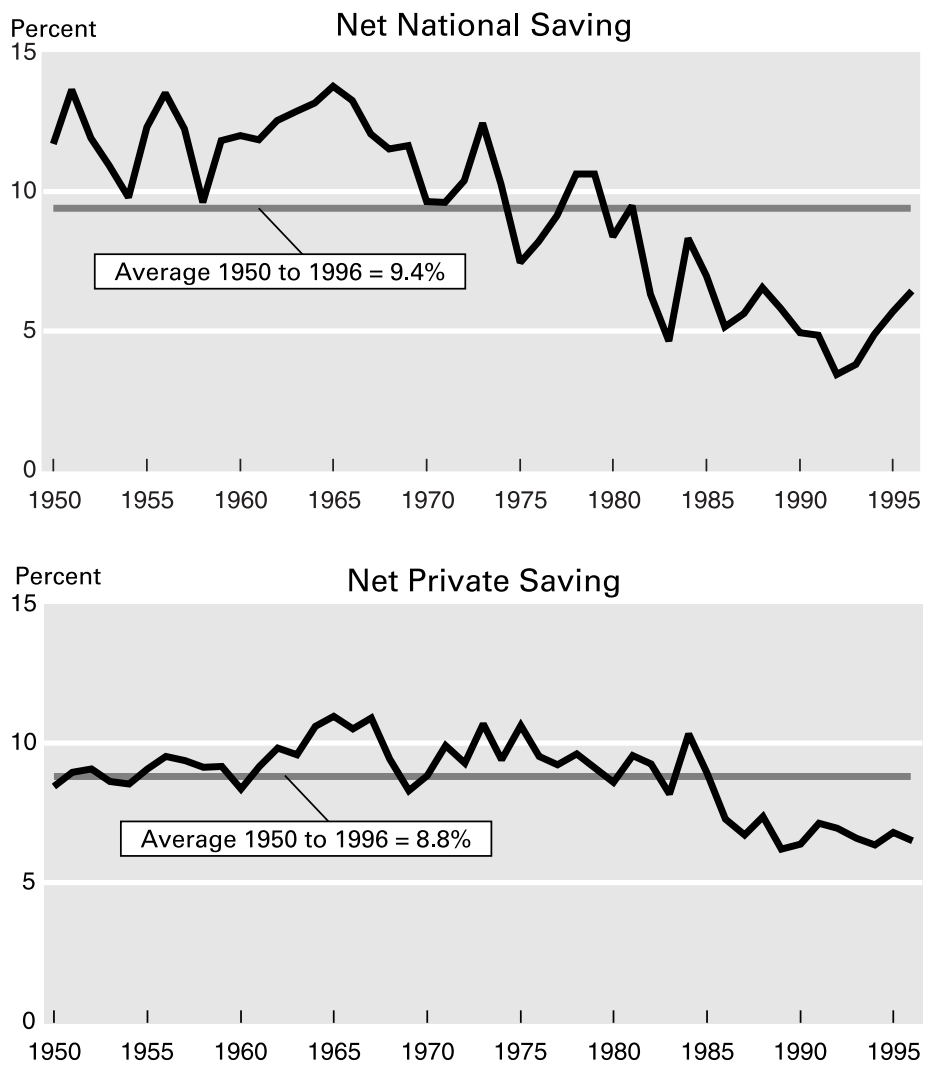

Percent $\quad$ Personal Saving
15

10
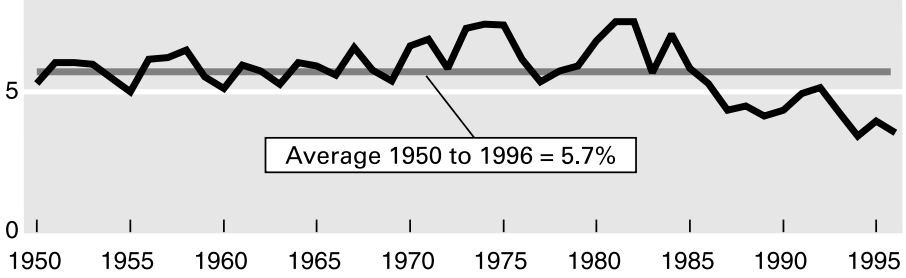

Source: National Income and Product Accounts. 
and despite the baby boomers fast approaching, or moving into, what should be the high-saving portion of their life cycle.

As currently designed, Social Security is usually thought to depress national saving, for reasons that will be discussed below. Therefore, one of the great attractions of Social Security reform is its potential to address two major issues simultaneously: repairing the long-term financial problems of Social Security and raising national saving. Specifically, to fix the long-term financial imbalance of Social Security, any proposal must contain some form of benefit cut and/or tax increase. Immediate and permanent across-the-board benefit cuts or tax increases should raise national saving. Thus, a range of reforms could presumably be designed to restore financial balance to Social Security and simultaneously raise national saving.

In this paper, we examine the extent to which Social Security reform can raise national saving. A variety of reform proposals have been put forth, ranging from adjusting the parameters of the current system to partial or complete privatization. Our goal in this paper is to highlight the issues, evidence, and uncertainties that arise in considering how implementing these proposals would affect national saving.

Many current characteristics of Social Security are relevant to its impact on saving. For analytical purposes, we divide these aspects into two broad categories: funding status and program design features. ${ }^{3}$ Social Security funding has traditionally been organized as an unfunded, or "pay-as-you-go" (PAYGO), system. In a PAYGO system, taxes collected from workers and employers in a particular year are paid out that same year as transfers (benefits) to retirees. The polar alternative is a fully funded system, where taxes collected from workers and their employers are paid into a fund and accumulate over time. Withdrawals for a given worker are made from the accumulated funds, rather than from currentyear tax collections.

The 1983 reforms placed Social Security on a partially pre-funded basis. This status, however, is temporary; when the baby boomers retire, benefits will rise to levels exceeding revenue, thus requiring the depletion of the accumulated trust fund. In the long run, based on current law, Social Security will not only be unfunded, but also out of financial balance. Thus, a basic improvement in funding status would involve bringing the system back into actuarial balance. Moving to a more fully funded system would create further improvements in funding status. The impact of these improvements on national saving generally depends on

${ }^{3}$ In designing a social security system from scratch, funding status and program features can be separated completely. In considering the transition from an unfunded to a fully funded system, there will typically be important links between changes in funding status and changes in program features. 
how the improvement affects both household behavior and the rest of the government budget.

Numerous program features also can affect saving. Specifically, Social Security provides mandatory, progressive annuities that are based on lifetime earnings and adjusted for inflation, retirement age, dependents, and current earnings. Benefits are financed by a flat tax on labor earnings up to an annual threshold, and they are integrated with the benefits paid by many private pension plans. These program features affect household saving decisions via redistribution of resources within and across generations, and alteration of incentives for labor supply and private saving.

Our major themes and conclusions are as follows. First, several important problems arise in analyzing the impact of Social Security reform on saving. One is that significant disagreement exists about the appropriate theoretical framework to use in studying saving. This caveat applies with particular force to analysis of Social Security: Presumably, at least part of the justification for the existence of Social Security in the first place includes the idea that a standard model of forward-looking, fully rational households operating in complete financial markets is incorrect in some important ways. More generally, substantial heterogeneity in saving behavior across households suggests the possibility that different types of models apply best to different groups of people.

In addition, the structure of Social Security is quite complex, so that in many cases the problem lies not so much in understanding how a new proposal would function, but in understanding how the existing program operates. Furthermore, because Social Security currently is not in longterm balance, some sort of change to the current system is inevitable. Thus, the effects of any particular proposal depend in part on how people expect Social Security to change in the absence of enacting that particular proposal.

Second, despite these problems, improving the program's funding status appears to be a crucial element of how Social Security reform can affect saving. Broad, but not universal, consensus indicates that moving toward a permanent, fully funded system-whether private or publicwould raise national saving, provided the change were not offset by other changes in government spending or taxes. This result holds under a variety of, but not all, theoretical frameworks; much indirect empirical evidence in the literature supports this view as well. However, the magnitude of the effect on saving depends on many factors.

Third, raising the saving rate is not necessarily the same thing as making households better off. Saving involves sacrificing consumption today in exchange for increased consumption in the future. It is not necessarily the case that all increases in saving - that is, all increases in future living standards-are worth the cost in forgone current consumption. In addition, in many cases, households save more precisely because 
they become worse off and save less precisely when they become better off. We point out several examples below.

A prominent example of this distinction concerns the transition from an unfunded to a funded system. In a pay-as-you-go system, the social security contributions of each generation of workers pay for the retirement of the generation that preceded it, whereas in a fully funded system, the contributions of each generation of workers pay for their own retirement. Thus, to switch from an unfunded to a funded system would, absent other changes, require one generation of workers to pay for two retirements-their own and the generation before them-or would require several generations to bear the transition costs. Such a transition may well raise national saving, by reducing the consumption of the transitional generations, but it will also make workers in those generations worse off. ${ }^{4}$

Fourth, the previous literature yields a wide range of estimates of the impact of the current Social Security program on saving. However, even if one were certain of the correct empirical effect of Social Security to date, it would be difficult to translate that result into an estimate of the impact of reform on saving. This difficulty occurs because the net effect of the current system is a combination of numerous factors that would change in different ways should reform occur.

Fifth, political economy issues are particularly important in understanding the impact of Social Security reform on saving. It is crucial to analyze Social Security reforms as they might be enacted, as opposed to how they might be proposed. For example, a surplus in the Social Security trust fund that is used to finance other government programs or tax cuts would not lead to an increase in national saving. In addition, to be enacted, Social Security reform must be voted on by workers and retirees alive at the time of the vote. This imposes constraints on the structure of reform, and will likely reduce the effect on saving. Other similar issues are highlighted below.

We do not address at least two closely related issues. One is whether Social Security reform is the best way to raise national saving. The second is the effect of higher saving on Social Security reform; that is, the extent to which higher saving would raise economic growth and thus improve society's ability to finance Social Security benefits. ${ }^{5}$ In addition, our focus is further narrowed by focusing primarily on the retirement portion of

\footnotetext{
${ }^{4}$ In a way it is misleading to call these "transition" effects. They are expected to persist for upwards of 70 years in some of the proposals, a period longer than the amount of time that Social Security has existed to date.

${ }^{5}$ For a comprehensive analysis of this issue, see Aaron, Bosworth, and Burtless (1989). Current projections in the Trustees' Report suggest that it is quite unlikely that the United States can grow its way out of the Social Security problem. To financially balance the system for the next 75 years, it is estimated that the growth rate of real wages would have to be boosted immediately and permanently by about 2 percentage points above its expected growth rate of approximately 1 percent.
} 
Social Security. Social Security also provides disability insurance and survivors' insurance for non-aged dependents, which we ignore throughout the paper.

The paper is organized as follows. The first section reviews previous theoretical findings, empirical research, and simulation models on the impact of the current Social Security system on saving, and discusses the implications of this literature for reform. The next section describes the features of major reform proposals. The third discusses how those features and other issues can affect national saving. A fourth section examines evidence on the impact of reform in other countries and a fifth discusses two previous analyses of social security reform. The final section provides a brief conclusion.

\section{How Has Social Security Affected Saving?}

\section{Theoretical Considerations}

The effect of social security on saving can be complex, and is the subject of a large literature. We begin with a simple model to investigate how social security affects individuals' saving, and then extend our discussion to include other factors.

A Simple Life-Cycle Model. We start with a model of a rational, forward-looking worker who faces no borrowing constraints or other capital market imperfections and no uncertainty. The worker has fixed labor supply and saves only for retirement. Suppose a social security system is introduced in this model (ignoring, for the moment, why social security would be needed under these conditions). Social security collects as tax a certain (small) percentage of wages and then pays retirement benefits proportional to these taxes.

Also, suppose that the implicit rate of return on the contributions is equal to the market interest rate; that is, that net social security wealth (NSSW) - the present value of benefits minus the present value of contributions-is zero, when the discounting occurs at the market interest rate. In this case, the introduction of social security would not change the worker's lifetime wealth. The worker would reduce his private saving by exactly the amount of his social security contribution; that is, he would substitute one asset for the other, because social security and private saving are perfect substitutes.

If NSSW were positive, social security would raise lifetime utility, and consumption in each period would rise. Therefore, private saving would fall by more than the worker's contribution. The asset substitution effect noted above would cause private saving to fall by the full amount of the contribution, while the increase in lifetime wealth would cause consumption to rise further and therefore cause saving to fall by an additional amount. If NSSW were negative, private saving would still 
decline, but by less than the social security contribution. The asset substitution effect would still cause a one-to-one drop in private saving, but the reduction in lifetime wealth would reduce consumption and hence raise saving.

Start-up of a PAYGO System. In a PAYGO system with a constant payroll tax, the implicit rate of return on social security contributions for workers who contribute throughout their careers is the sum of the growth rates of productivity and of the labor force (Samuelson 1958). These workers receive negative net social security wealth in the empirically plausible case where their implicit return is below the comparable market rate of return (adjusted for risk). In contrast, members of the initial generation of beneficiaries typically contribute only for short periods, if at all. Thus, their implicit return is much higher and they receive on average positive net social security wealth. These factors create important differences between the introductory and mature phases of a PAYGO system with regard to the effect on saving.

In a life-cycle model, after the introduction of a PAYGO system, the initial generation of beneficiaries raise their current consumption by more than other generations reduce their current consumption, for two reasons. First, the elderly have higher propensities to consume than workers. Second, the wealth transfer is paid for not just by current young workers (with lower propensities to consume) but also by future generations, who cannot reduce their consumption at the time the program is introduced because they are not yet alive. Thus, private saving falls. Since no public saving occurs in a pure PAYGO system, national saving also falls. ${ }^{6}$ In the United States, Social Security coverage and benefits were expanded for several decades after the program was enacted in 1935. Each such expansion can be thought of as a "mini-start-up," providing windfall benefits either to certain groups of newly covered workers who were near retirement via coverage expansions or to all retirees and near-retirees via benefit expansions. These expansions have, in a sense, extended the start-up phase, in which the effect on national saving is negative.

If Social Security had been fully funded, initial generations would not have received the wealth transfers noted above. Under this simple life-cycle model, then, fully funding social security from the beginning would have prevented the reduction in saving induced by the windfall gain to the initial generation(s).

Does the Funding Status Matter? While funding status affects national saving in the life-cycle model, it is neutral in other theoretical frameworks. The central role of funding status has been challenged by Barro

6 Samuelson (1958), Diamond (1965), Aaron (1966), and many others discuss the conditions under which welfare improves or declines in response to the introduction of a PAYGO social security system. 
(1974, 1989). A PAYGO social security system is simply a mandated public transfer from the currently young to the currently old. Barro notes that if bequests (or other intergenerational transfers) from the old to the young are altruistically motivated and are pervasive across families, then a forced public transfer from the young to the old would lead to completely offsetting voluntary private transfers from the old to the young. Under these circumstances, the funding status of social security has no effect on national saving.

A large literature describes a variety of implications of Barro's model; for examples, see Bernheim (1987b, 1989); Altonji, Hayashi, and Kotlikoff (1992); and Seater (1993). While we note the presence of professional disagreement on this topic, our reading of the evidence is that transfers appear to be neither universal nor predominantly altruistic in nature. Thus, our conclusion is that the funding status of social security does influence national saving.

Borrowing Constraints. Capital market imperfections can affect the degree to which social security crowds out private saving. Hubbard and Judd (1986) show that borrowing constraints can limit workers' responses to social security taxes. This reduces the aggregate decline in private saving caused by asset substitution, but can also lead to a reduction in consumer welfare.

Labor Supply and Retirement Age. Social security may also affect the age at which people choose to retire. Feldstein (1974) shows that if social security induces earlier retirement, workers need to save more while working to finance their longer retirement period. Thus, the net effect of social security on private saving would depend on the relative strengths of this retirement effect on saving and the asset substitution effect discussed above.

In the simple life-cycle model above, taxes and benefits are perfectly aligned, so that the net tax rate imposed by social security is zero when NSSW is zero. To the extent that benefits and taxes are imperfectly linked, the effective tax rate on labor income could be higher or lower than zero. This would influence labor supply, which would in turn affect saving (Auerbach and Kotlikoff 1987; Feldstein and Samwick 1992).

Uncertain Longevity. By providing annuities, social security insures against some of the risks of uncertain longevity. Similar insurance may be unavailable in the private sector for the familiar reason of adverse selection (Diamond 1977). Abel (1985), Hubbard (1987), Kotlikoff, Shoven, and Spivak (1987), and Hubbard and Judd (1987) show, in partial equilibrium models with a functioning capital market but no annuity market, that social security can reduce precautionary saving and raise individual welfare when lifespan is uncertain.

Uncertain Wages. With uncertain and uninsurable earnings, working households save for both precautionary and retirement reasons (Engen and Gale 1993, Samwick 1995). Precautionary saving against earnings risk 
is relatively important for younger individuals who face substantial earnings uncertainty and have a less urgent need to save for retirement. As people age, some earnings uncertainty is resolved, and stocks of assets are accumulated. Both of these factors reduce the demand for further precautionary saving, while retirement saving rises as retirement approaches. Thus, as people age, the composition of their saving shifts toward retirement saving.7

The effect of social security contributions-illiquid saving for retirement- on saving depends in part on the substitutability of social security contributions and other saving. If households find social security and other saving to be good substitutes-as in the initial simple model above-social security will reduce private saving. In contrast, if social security and other saving are poor substitutes, households will not reduce their other saving in response to required social security contributions. The latter will occur for households who save primarily as a precaution against earnings risk, as social security benefits generally cannot be received earlier than age 62 . Thus the offset should tend to be less than one-for-one for younger households but increase as the household ages and retirement saving becomes more important. Therefore, precautionary saving against uncertain income reduces the effects of social security on saving relative to a certainty life-cycle model (Samwick 1995). However, because younger households (optimally) save little for retirement on their own, forced social security contributions may reduce their welfare.

Merton (1983) examines the role of social security when markets for insuring risky returns from human capital do not exist. He shows that social security can reduce or eliminate the inefficiency from the missing market. This reduces the need for precautionary saving, but raises consumer welfare.

Intragenerational Redistribution. The extent to which social security is progressive within generations is uncertain. On one hand, the ratio of benefits to earnings falls as the level of earnings rises, which is progressive. On the other hand, wealthier people tend to live longer and therefore to collect more in benefits.

To the extent that net intragenerational redistribution toward lowerincome households exists and saving rates are lower for lower-income households, social security reduces private saving. Dynan, Skinner, and Zeldes (1997) provide evidence from a variety of data sources that

${ }^{7}$ Kennickell, Starr-McCluer, and Sunden (1997) report that the most common reason for saving given in the 1995 Survey of Consumer Finances (SCF), as in previous surveys, was to increase liquidity, a category that includes a variety of precautionary motives; retirement was the second most prevalent response. Engen and Gale (1993) show that these responses in the SCF on motives for saving vary by age: Older households are less likely to save for precautionary reasons and more likely to save for retirement than are younger households. 
households with higher permanent income save at higher rates, controlling for other factors. This suggests that the intra-generational redistribution of social security probably tends to lower aggregate saving.

However, a second effect works in the opposite direction. Bernheim and Scholz (1993) and Gale (1995) find that the offset between pensions and other wealth differs for lower-income and higher-income households. Specifically, Gale (1995) finds that more highly educated households tend to offset reductions in pension wealth, including social security, with increases in non-pension wealth, whereas less educated households tend not to offset pension wealth. This implies that a redistribution of social security wealth from high- to low-income households should cause high-income households to raise their other saving significantly, but should not cause low-income households to reduce their saving by much. As a net effect, this should raise private saving. Thus, the effect of within-generation redistribution of social security wealth on private saving depends on differences across income classes in both the propensity to save and the tendency to offset pension wealth with other wealth.

Private Pensions. Social security may also affect saving through its influence on pension plans. The integration of social security and private pensions suggests at least some substitution between the two. To the extent that private pensions are unfunded and are substitutes for social security, an unfunded public social security system would merely replace an unfunded private pension. At first glance, this might appear to leave national saving unchanged. However, an unfunded private pension plan is a corporate liability that should be reflected in the value of corporate equities. Thus, an expansion of social security that reduced unfunded private pension liabilities would increase equity values, increase consumption by equity owners, and reduce private saving. Since public saving is unaffected by a PAYGO system, national saving would fall as well.

General Equilibrium Effects. Changes in wages and the rate of return to capital caused by changes in saving and labor supply in response to social security can have important general equilibrium feedback effects. These effects can serve to amplify or dampen the partial equilibrium effects (Kotlikoff 1979a).

The Underlying Model of Saving. All of the analyses above implicitly or explicitly focus on models where households make rational decisions with foresight. Two potential problems are found with such models in the current context. First, some evidence suggests that people may not act in such a manner (Thaler 1994; Bernheim 1997). Second, it is harder to explain the existence of social security unless some people do not act rationally. Presumably a principal reason why social security exists is the belief that at least some proportion of the population needs to be compelled to save. 
Different underlying models offer the potential for radically different effects of social security on saving. One possibility is simply that households are myopic, and do not plan for retirement. In this case, provision of social security would not cause any of the asset substitution, early retirement, or precautionary saving effects described above. Social security would thus leave private saving unchanged. A second possibility is offered by Katona (1965), who considers a version of a goal gradient hypothesis. In this view, the closer a person gets to achieving a goal, the harder he tries to reach the goal. Thus, for example, social security, by providing a base of adequate retirement income, could encourage people to save more for retirement than they had been by making the goal of adequate retirement living standards more attainable.

A third possibility is a model where households choose to undersave when social security does not exist, because they believe that society will not allow them to be destitute in old age. In this framework, society may find it beneficial to institute social security to force such households to save enough for their own retirement, and social security would raise saving through this channel (Kotlikoff 1987). ${ }^{8}$

\section{Empirical Evidence}

The empirical literature has produced a wide variety of conclusions regarding social security and saving. The absence of consensus is due both to the number of theoretical undercurrents and the lack of clean empirical tests.

Time Series Evidence. Feldstein (1974) examines the effects of net social security wealth (NSSW) on aggregate consumption using time series data for the United States. He finds that Social Security reduces household saving by 30 to 50 percent. Feldstein (1996), using a similar methodology, updates his results with the addition of 21 years of data and finds much the same result-that Social Security reduces private saving by almost 60 percent.

These results have come under substantial criticism. Specifically, the inclusion of variables that measure the overall level of economic activity, such as the unemployment rate, reduces the coefficient and/or eliminates the significance of the coefficient on Social Security (Munnell 1974). Leimer and Lesnoy (1982) find that correcting a programming error in the calculation of NSSW leads to estimates that imply either that Social Security causes an implausibly large increase in private saving or that Social Security has a significantly smaller negative effect on saving.

${ }^{8}$ Laibson (1996) offers a model of hyperbolic discounting that appears to suggest that social security would not reduce private saving by as much as a conventional model would indicate. 
Feldstein (1982) argues that when the corrected variable is used, results similar to his original paper are obtained.

Perhaps even more important, Leimer and Lesnoy (1982) point out the crucial role of expectations in the formation of NSSW. Given the frequency of legislative changes in the Social Security benefits formulas, they note several plausible alternative sets of assumptions that workers may make about their future benefits. They also note that it is impossible to determine which set of assumptions workers actually use, and that the estimated effects of Social Security on saving are extremely dependent upon which assumption is chosen.

Auerbach and Kotlikoff (1983) use a life-cycle simulation model to generate synthetic aggregate time series data. The underlying model indicates that an unfunded social security program would reduce national saving, but regressions using the synthetic data yield a wide variety of conclusions, including positive, negative, and zero coefficients on the social security variable. The authors conclude that the time series estimates are very sensitive to a variety of specifications.

In general, these studies show that time-series estimates of the saving effects of Social Security depend on the time period used, the specification of NSSW, and the inclusion of other aggregate variables such as the unemployment rate. Any study based on aggregate data faces formidable econometric problems in measuring changes in expected real net NSSW and in holding constant the other factors that affect consumption and saving. Moreover, the Lucas (1976) critique suggests that a stable aggregate consumption (or saving) function may not even exist. Aaron's (1982) summary of the time series evidence still seems valid: "Almost all participants have concluded that essentially nothing can be learned about the effects of social security on saving from time series analysis." 9

Cross-Section Studies. Cross-sectional household studies have yielded a wide variety of estimates, from almost complete offset of social security wealth with reductions in other wealth to almost no offset. ${ }^{10}$ Although disaggregated data on households possess a number of potential advantages over time series data, cross-sectional analyses also suffer from a variety of econometric problems.

First, it is difficult to generate variation in social security benefits that is plausibly exogenous with respect to observed or unobserved factors that determine households' saving. Second, information on households'

${ }^{9}$ A number of studies have compared social security and saving by examining time series patterns across countries. These studies have generally been inconclusive for the same reasons as the U.S. time series evidence. See Aaron (1982).

10 Studies in this vein include Feldstein and Pellechio (1979); Kotlikoff (1979b); Diamond and Hausman (1984); Blinder, Gordon, and Wise (1981); Dicks-Mireaux and King (1984); Hubbard (1986); Bernheim (1987a); Leimer and Richardson (1992); Samwick (1995); and Gale (1995). 
expectations of social security benefits is necessary, but often difficult to obtain. Third, almost all cross-sectional studies overstate the impact of social security on saving because they control for cash wages and pensions separately but do not adjust for these separate controls. Studies that control for lifetime resources instead of cash wages present a possible exception to this rule, but even these studies will generate incorrect estimates of the extent to which increases in social security wealth are offset by reductions in other wealth if the true offset is less than 100 percent (Gale 1995). Fourth, studies that do not include age, life expectancy, and retirement age as explanatory variables will systematically overstate the impact of social security on saving. For all of these reasons, the cross-sectional studies are also inconclusive. It is worth noting, however, that all of the econometric problems listed above lead to overstatements of the effects of social security on saving (Gale 1995).

A notable feature of the cross-sectional analyses above is that most of the studies examine the impact of social security on broad measures of wealth that include other financial assets, debt, housing, and other net worth. This is an important consideration, as studies that examine the effects of pensions on broad measures of wealth tend to find more offset than studies that measure the impact on narrow measures (see Avery, Elliehausen, and Gustafson 1986; Gale 1995; Engen and Gale 1997). A key factor in the analysis of social security reform is the extent to which households would reduce their other wealth if they were provided with mandatory retirement accounts. Analyses that examine only how pensions affect financial assets will systematically understate the amount by which households will offset their wealth in mandatory retirement accounts.

\section{Simulation Studies}

Simulations can help shed light on the plausible empirical magnitudes of the saving effects of social security. Kotlikoff (1979a) and Auerbach and Kotlikoff (1987) demonstrate that in a certainty life-cycle, overlapping-generations, general equilibrium model, an unfunded social security program can impose a large negative effect on the capital stock. In this model, intergenerational transfers to initial beneficiaries and the wealth substitution effect of social security, which decrease saving, dominate the retirement effect of social security, which increases saving.

Samwick (1995) demonstrates that the large negative impact found above occurs because of the assumption that the economic environment is certain. Incorporating uncertain labor earnings, Samwick shows that the negative effects of social security on saving are smaller under conditions where precautionary saving is an important motive. Social security wealth tends to crowd out retirement saving, but illiquid social 
security wealth represents an imperfect substitute for precautionary saving against labor earnings uncertainty. Overall, then, as with the empirical evidence, simulations do not offer a definitive conclusion on the magnitude of the effect of social security on saving.

\section{The Implications of Prior Analysis for Social Security Reform}

The literature has reached inconclusive results on the impact of social security on national saving, although almost all studies show some displacement of private saving. It is worth noting, however, that even if there were absolute certainty about the overall effect of the existing program on national saving, the implications of that finding for reform proposals would have to be interpreted very carefully. For example, none of the studies described above are able, or even try, to separate the impact of social security provisions that affect retirement saving versus precautionary saving. While it is true that households need not make literal distinctions between these types of saving, it is also true that reform could change the relative importance of the impact of social security on retirement versus precautionary motives. More generally, empirical studies estimate the joint effects of all of the features of social security. Understanding proposed reforms requires more detailed knowledge about the impact of each of these features, rather than just their aggregate effect, because a reformed system would involve a different combination of these features.

\section{Proposals for Reform}

This section outlines the basic characteristics of five Social Security reform proposals: three developed by members of the 1994-1996 Advisory Council on Social Security (1997) plus two leading proposals for full privatization.

Table 1 presents one way of categorizing the reform proposals. We examine the extent to which each plan would shift the system toward private accounts, and to defined contribution accounts. We then examine investment options for the public and private components of the plan. Next, we list changes in the long-term funding status of the plan, permanent tax changes, and transitional taxes. Finally, we list changes in the level and structure of benefits, requirements for annuitization, and retirement age.

\section{Maintenance of Benefits Plan}

The Maintenance of Benefits (MB) plan, as the name implies, would maintain much of the present Social Security benefit and tax structure, with certain changes to effectively increase tax revenue and decrease 
benefits. In particular, the plan would raise revenue by including all Social Security benefits in excess of already taxed employee contributions in federal taxable income, and by phasing in a redirection of some taxes on OASDI benefits now going to the HI trust fund. Moreover, all state and local government employees hired after 1997 would be covered under Social Security.

The proposal would either extend the Social Security benefit computation period from 35 to 38 years, reducing estimated benefits by an average of 3 percent, or increase the payroll tax rate in 1998 by 0.3 percentage points. In either case, the plan would also raise long-term revenues by enacting a permanent 1.6 percent payroll tax increase in 2045.

The plan allows investment of 40 percent of trust fund assets in equity indices. Combined with the Advisory Council's estimate that real annual stock returns have averaged 7 percent, compared to 2.3 percent for Treasury bills, the total return on the trust fund would be as high as 4.2 percent. The proposal also suggests that consideration be given to investing some of the trust fund's portfolio in corporate bonds and other debt instruments.

\section{Individual Accounts Plan}

The Individual Accounts (IA) plan would create individual accounts alongside the current Social Security system. Like the MB plan, this plan involves increased income taxation of benefits, coverage of new state and local government employees, and lengthening of the benefit computation period. In contrast to the MB plan, it proposes overall benefit reductions by accelerating the already scheduled increase in the age of eligibility for full benefits up to year 2011 and then automatically increasing that age with projected longevity. The growth of benefits would be slowed further for middle- and high-wage workers by changes to the current benefit schedule.

The plan would also impose a mandatory contribution by workers equal to 1.6 percent of covered payroll, which would be allocated to individual defined contribution accounts. These accounts would be administered by the government with limited investment choices available to individuals. The accumulated funds would be converted to single, or joint, minimum-guarantee indexed annuities when the individual elects retirement, any time after age 62 .

\section{Personal Security Accounts Plan}

The Personal Security Accounts (PSA) plan would create even larger, fully funded individual accounts that would replace a portion of Social 


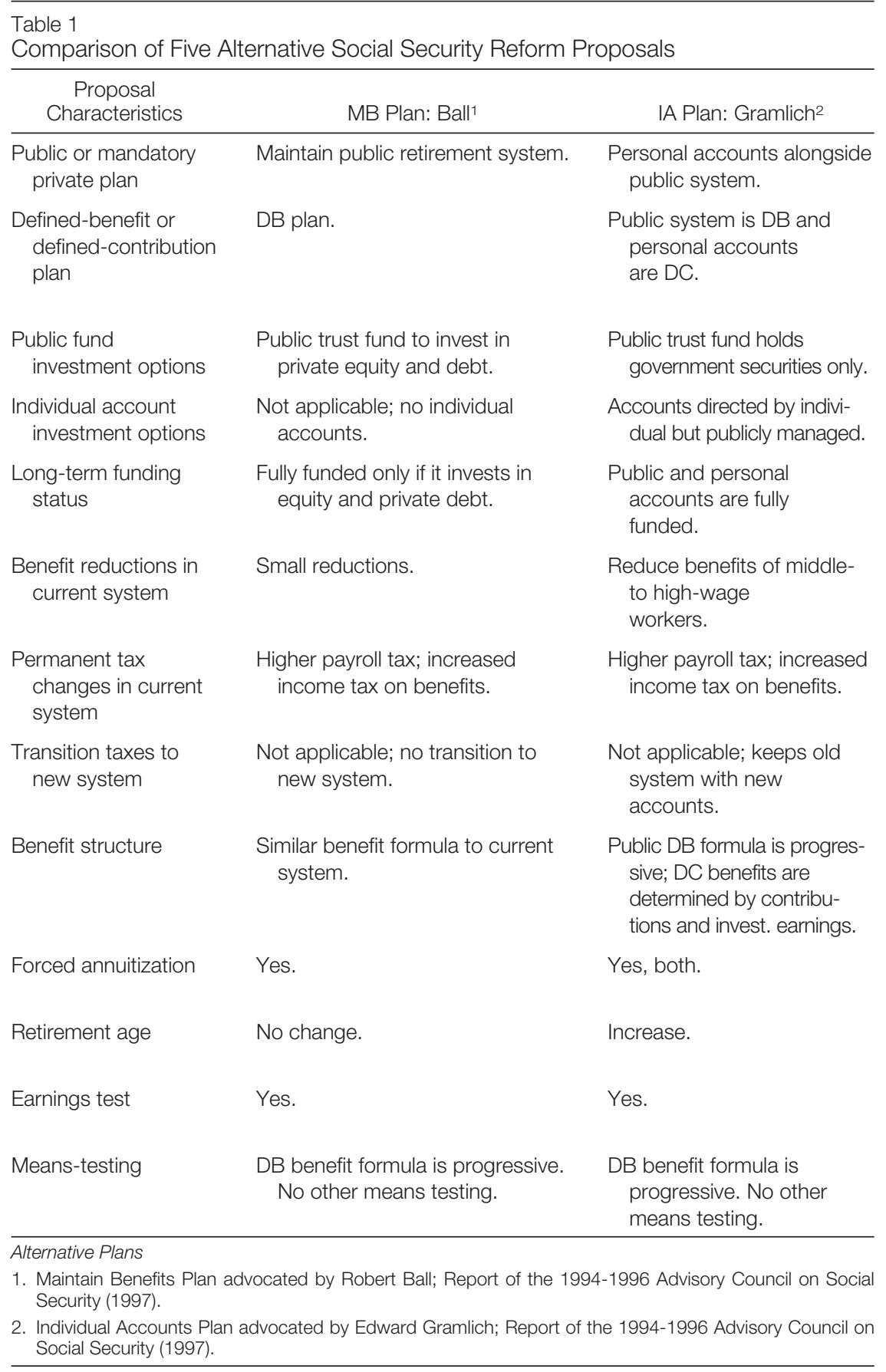


EFFECTS OF SOCIAL SECURITY REFORM ON PRIVATE \& NATIONAL SAVING

\begin{tabular}{|c|c|c|}
\hline $\begin{array}{c}\text { PSA Plan: } \\
\text { Schieber-Weaver }\end{array}$ & $\begin{array}{l}\text { PSS Plan: } \\
\text { Kotlikoff-Sachs }\end{array}$ & $\begin{array}{l}\text { MIRA Plan: } \\
\text { Feldstein-Samwick }{ }^{5}\end{array}$ \\
\hline $\begin{array}{l}\text { Payroll tax finances } \\
\text { benefits from old } \\
\text { system. }\end{array}$ & $\begin{array}{l}\text { Retail sales tax finances } \\
\text { benefits from old system. }\end{array}$ & $\begin{array}{l}\text { Payroll tax finances benefits } \\
\text { from old system. }\end{array}$ \\
\hline $\begin{array}{l}\text { Flat public DB benefit; DC } \\
\text { benefits are determined } \\
\text { by contributions and } \\
\text { invest. earnings. }\end{array}$ & $\begin{array}{l}\text { Public matching of indiv. } \\
\text { contributions, along with } \\
\text { invest. earnings, } \\
\text { determine DC benefits. }\end{array}$ & $\begin{array}{l}\text { DC benefits are determined } \\
\text { by contributions and } \\
\text { investment earnings. }\end{array}$ \\
\hline Public-yes. Private-no. & Yes. & Unspecified. \\
\hline Increase. & $\begin{array}{l}\text { Not applicable to } \\
\text { DC plan. }\end{array}$ & $\begin{array}{l}\text { Not applicable to } \\
\text { DC plan. }\end{array}$ \\
\hline Yes. & $\begin{array}{l}\text { Not applicable to } \\
\text { DC plan. }\end{array}$ & Not applicable to DC plan. \\
\hline No means testing. & $\begin{array}{l}\text { Contribution match is } \\
\text { phased out for high } \\
\text { income. }\end{array}$ & No means testing. \\
\hline $\begin{array}{l}\text { Private accounts with small } \\
\text { public benefit guarantee. }\end{array}$ & $\begin{array}{l}\text { Phase out public system } \\
\text { with personal accounts. }\end{array}$ & $\begin{array}{l}\text { Phase out current public } \\
\text { system with private } \\
\text { accounts. }\end{array}$ \\
\hline $\begin{array}{l}\text { Public system DB, private } \\
\text { accounts DC. }\end{array}$ & $\begin{array}{l}\text { DC plan replaces public DB } \\
\text { plan. }\end{array}$ & $\begin{array}{l}\text { DC plan replaces public DB } \\
\text { plan. }\end{array}$ \\
\hline $\begin{array}{l}\text { Public trust fund holds } \\
\text { government securities } \\
\text { only. }\end{array}$ & $\begin{array}{l}\text { Not applicable; no public } \\
\text { trust fund. }\end{array}$ & $\begin{array}{l}\text { Not applicable; no public } \\
\text { trust fund. }\end{array}$ \\
\hline $\begin{array}{l}\text { Individual directs and } \\
\text { manages account. }\end{array}$ & $\begin{array}{l}\text { Accounts are publicly } \\
\text { directed and managed. }\end{array}$ & $\begin{array}{l}\text { Individual directs and } \\
\text { manages account. }\end{array}$ \\
\hline $\begin{array}{l}\text { Public and private accounts } \\
\text { are fully funded. }\end{array}$ & $\begin{array}{l}\text { Personal accounts are fully } \\
\text { funded. }\end{array}$ & $\begin{array}{l}\text { Private accounts are fully } \\
\text { funded. }\end{array}$ \\
\hline $\begin{array}{l}\text { Reduce public benefits to } \\
\text { basic flat benefit. }\end{array}$ & $\begin{array}{l}\text { No reduction in promised } \\
\text { benefits; no new benefits. }\end{array}$ & $\begin{array}{l}\text { No reduction in promised } \\
\text { benefits; no new benefits. }\end{array}$ \\
\hline $\begin{array}{l}\text { Reduce payroll tax } \\
\text { allocated to public } \\
\text { system. }\end{array}$ & $\begin{array}{l}\text { Not applicable; phases out } \\
\text { public DB system. }\end{array}$ & $\begin{array}{l}\text { Not applicable; phases out } \\
\text { public DB system. }\end{array}$ \\
\hline \multicolumn{3}{|c|}{$\begin{array}{l}\text { 3. Personal Saving Accounts Plan advocated by Sylvester J. Schieber and Carolyn Weaver; Report of the } \\
\text { 1994-1996 Advisory Council on Social Security (1997). } \\
\text { 4. Personal Security System Plan advocated by Laurence Kotlikoff and Jeffrey Sachs (1996). } \\
\text { 5. Mandatory Individual Retirement Accounts Plan advocated by Martin Feldstein and Andrew Samwick } \\
\text { (1996). }\end{array}$} \\
\hline
\end{tabular}


Security. Workers would direct 5 percentage points of the current payroll tax into a PSA. In contrast to the IA plan, these accounts would be managed privately, with fewer restrictions on investments and no requirement to annuitize the wealth. The balance of the payroll tax would fund modified retirement, disability, and survivor benefits. When fully phased in, the modified retirement program would offer all full-career workers a flat dollar benefit (the equivalent of $\$ 410$ monthly in 1996, with the amount increased to reflect increases in national average wages prior to retirement) plus the proceeds of their PSAs. A payroll tax increase of 1.52 percentage points would persist for a transition period of 72 years.

Like the IA plan, PSAs would raise benefits taxation, add state and local employee coverage, and accelerate the already-scheduled increase from 65 to 67 in the age of eligibility for full retirement benefits, with the age increased in future years to reflect increases in longevity. Unlike the IA plan, the PSA plan would gradually increase the age of eligibility for early retirement under the current system from 62 to 65 (although workers could begin withdrawing funds from their PSAs at age 62), reduce future benefits for disabled workers, reduce benefits for spouses who never worked outside the home, and increase benefits for many elderly survivors.

If PSA assets were allocated to equities in the same proportion as 401(k) balances are, the flat benefit plus income from PSAs would, on average, exceed benefits promised under the current system for all income groups.

\section{Kotlikoff-Sachs Plan}

The Kotlikoff-Sachs (KS) plan (1997) would phase out the retirement portion of the public system and replace it with a system of defined-contribution personal accounts. The accounts would be fully funded and publicly managed and directed or at the very least heavily regulated and supervised. No changes in current public benefits would be made, but no future benefits would accrue either. The KS plan retains progressivity by providing for matching government contributions to the accounts, where the match rate declines and eventually vanishes as income rises. The plan would require annuitization of the personal accounts upon retirement. A national retail sales tax or value added tax would be enacted to finance benefit payments due under the current system and the government matching contributions. This tax is estimated to be set at 10 percent or less initially and to decline to as low as 2 percent within 40 years. 


\section{Feldstein-Samwick Plan}

Feldstein and Samwick $(1996,1997)$ present a mandatory individual retirement account (MIRA) plan. ${ }^{11}$ Under this plan, benefit levels are left as currently projected, but the benefits are financed by shifting gradually to a privatized system of individual accounts. No current benefits are cut, but no future benefits accrue in the PAYGO part of Social Security. The improved funding status is financed from a transitional increase in payroll taxes. Feldstein and Samwick estimate that the transition would require an initial addition of 2 percentage points to the payroll tax for mandatory saving. The combined payroll tax and mandatory saving contribution rate would fall below the current 12.4 percent payroll tax within 20 years, and would fall to as low as 2.1 percent after the transition is completed in 75 years. Individual accounts would be completely privately managed and directed, with no requirement for annuitization. Under the plan, the government would contribute to each account the extra federal, state, and local corporate income and property taxes that would be collected as a result of increased saving. All redistribution within Social Security would be eliminated.

\section{Other Proposals}

The Bipartisan Commission on Entitlement and Tax Reform (1995) proposes changes to the current system that effectively would raise taxes and cut benefits but (similar to the Maintenance of Benefits plan above) would not institute mandatory individual saving accounts. The Committee for Economic Development (1997) proposal is similar to the Individual Accounts plan, and would institute a small mandatory saving account on top of a modified public social security system. Petersen (1996) proposes to subject all federal benefits to a means test. The portion of federal entitlements that would be deducted rises with family income from private pensions, assets, and earnings. Households would lose 10 percent of all benefits that raised their total income above $\$ 40,000$, an additional 10 percent of benefits that raised their income above $\$ 50,000$, and so on. A household with more than $\$ 120,000$ in income would lose 85 percent of its benefits.

\section{How Would Social Security Reform Affect Saving?}

To analyze the impact of the reform proposals on national saving, we proceed in several steps. First, we examine the impacts of particular

${ }^{11}$ Feldstein and Samwick (1996) call the plan a MIRA plan, whereas Feldstein and Samwick (1997) refer to the plan as a Personal Retirement Account plan and drop the provision that it be mandatory. However, they assume that everyone switches to the plan even if it is not mandatory. 
components of the proposals: improving funding status, investing the trust fund in private securities, establishing personal defined contribution accounts, transition taxes, and means testing. Next, we discuss related items that are not specific to any proposal, but may be essential nonetheless: the role of integration between private pensions and Social Security, a variety of political economy issues, and public confidence in the Social Security system. In the following sections, we turn to evidence from other countries and discuss recent estimates of the impact of social security reform.

\section{Improving the Funding Status}

In the absence of other changes, improving program funding status should raise public saving and national saving. Offsetting responses, however, could arise from either the household sector or the government sector.

Households could respond to improved Social Security funding by adjusting their bequests and other intergenerational transfers to fully offset the impact of changes in funding status on saving. However, as noted above, the evidence strongly suggests that intergenerational transfers will offset only a small portion, if any, of these changes. A second possible channel of household response involves altering saving or labor supply behavior in response to the structure of the changes that improve the funding status. For example, the introduction of strict, asset-based, means tests would reduce benefits and hence improve the funding status of Social Security, but it could also reduce private saving substantially. This is an issue of program design, rather than funding status, and we defer discussion until later. Government could offset the improvement in funding status by using the trust fund balances to finance increased government transfers, government consumption, or tax cuts.

Privatizing Social Security is neither necessary nor sufficient to improve funding status. To see this, consider a stark version of privatization, one that would replace the current mandatory defined-benefit pension plan with a mandatory defined-contribution pension plan. Such a change would require workers to immediately switch their contributions to private saving accounts, with no change in current benefits, while the government would have to borrow to meet already promised benefit payments. This would make explicit the previously implicit liability created by future benefits. Thus, privatization would adjust the structure of the program but would not necessarily alter the government's total (explicit and implicit) liabilities. Only if policies were changed to make total government debt decrease would Social Security funding status actually improve (Mitchell and Zeldes 1996).

More generally, national saving will be affected in the same way regardless of whether Social Security is pre-funded as a private or a 
public program. Specifically, the social return to an additional dollar of saving is the same whether that saving accrues through private saving or through improving the funding status of Social Security. Private saving makes the dollar available for private investment; the social gain is the pre-tax rate of return on the investment. In a pure PAYGO system, a worker's return on a Social Security contribution is productivity plus population growth; this is typically less than the return available in the private economy. But the social gain from improving the funding status by a dollar exactly equals the gain through private saving: The dollar reduces the amount the federal government has to borrow from the public, leaving an additional dollar of private saving for new private investment (Bosworth 1996).

\section{Investing the Trust Fund in Private Securities}

Other things equal, investing trust fund assets in private equities does nothing to raise national saving, it simply shifts the ownership of existing assets. The trust fund currently invests its surpluses in government bonds. Shifting part of that investment to private securities could raise the relative demand for private securities and reduce the relative demand for government bonds. This may reduce the relative yield on private securities and raise the relative yield on government bonds. This in turn could induce private investors to shift out of equities and private bonds and into government bonds. The total amount of debt and equity would remain the same, as would the productive capacity of the economy, but owners would have exchanged assets. In particular, funds that the federal government formerly borrowed from the Social Security trust fund would instead be borrowed from private investors. This would increase the government debt held by the public and could possibly raise government borrowing rates, which would further increase government borrowing.

Thus, investing the trust fund in private securities is independent of raising national saving. Rather, its justification stems from the fact that, as noted above, the social return is the same for an added dollar of pre-funded Social Security and an added dollar of private saving. Investing the trust fund in private securities permits the Social Security trust fund itself to accumulate more of the social benefits of its investments than is currently the case. Any gain clearly comes at the expense of the rest of the government budget and other investors, and also raises political economy issues as discussed below.

\section{Establishing Personal Defined Contribution Accounts}

A key feature of many reform proposals is the establishment of mandatory personal-level, defined-contribution accounts. These accounts 
would exist alongside traditional Social Security benefits in several of the proposals and would completely replace traditional benefits in the full privatization proposals. The accounts raise several interesting issues regarding saving.

Public versus Private Management. Basic economic analyses of the impact of defined contribution accounts on saving are independent of whether the accounts are managed within the government or by the private sector. As discussed below, however, important political economy issues arise in each case.

Changing the Risk Properties of Social Security Benefits. By shifting the source of retirement benefits from a defined-benefit (DB) plan toward a defined-contribution (DC) plan, personal accounts would introduce a new source of risk. Benefits in DB plans are based on lifetime earnings, whereas benefits in DC plans depend on the level of contributions (which presumably is related to lifetime earnings) and investment risk. This added source of risk could increase or reduce the overall level of risk faced by workers, and thus could reduce or increase their precautionary saving.

Changing the Redistributive Properties of Social Security Benefits. The shift to personal accounts would also likely alter the redistributive properties of Social Security. ${ }^{12}$ Because the benefit replacement schedule for Social Security is progressive and benefits are based upon the 35 highest earning years, Social Security provides insurance against some earnings risk. Changing the risk would in turn alter households' precautionary saving.

A second redistributive effect would occur because defined-contribution accounts may in fact be regressive. As Turner (1997) points out, high-income households tend to live longer and thus benefit more from any annuitization of DC accounts. High-income households also may make better investment choices. Finally, administrative costs, which have a substantial fixed-cost element, could comprise a smaller proportion of account balances for high-income households than for low-income households. These three factors suggest that DC plans would redistribute resources toward higher-income households. The effects of such intragenerational redistributions on saving are discussed in the first section of this paper.

Personal accounts would also tighten the link between contributions and benefits, which could reduce the perceived marginal tax rate on households' labor supply (Kotlikoff 1996). If households react by increas-

12 This change is not a required effect of moving to DC plans, however. As discussed earlier, the Kotlikoff-Sachs (1997) proposal introduces redistribution within a system of defined contribution accounts by stipulating government matching contributions that phase out as income rises. 
ing their labor supply, saving would rise. The strength of this effect depends on workers' perceptions of the existing link between taxes and benefits and on the sensitivity of labor supply to changes in this link (see Devine, this volume).

Effects on Other Saving. The establishment of personal accounts may affect other saving directly, aside from those effects due to changes in risk and redistribution. Loosely speaking, two contrasting cases are possible. In the first case, workers continue to contribute the same amount in payroll taxes, but a portion of those taxes is funneled into private, defined-contribution accounts. Workers will presumably earn higher returns on the contributions placed in the personal accounts than the implicit return on their traditional Social Security benefits. Thus, in this case, the presence of a personal account raises benefit levels for the individual worker, with no change in contribution amounts. The impact of such a change on saving depends on how households make saving decisions. A household that is oblivious to its future needs will not reduce its other saving, so that the added benefits will represent new saving as they accrue. A life-cycle household will see the benefits as an increase in lifetime wealth and hence spread the benefits over all years from the present to the end of life. Thus, it will reduce its other saving. An alternative model presumes that households undertake target saving. An example of target saving is given by financial planning programs that ask households to specify a level of retirement income before determining how much the household needs to save. For a target saver, the increase in benefits will cause a one-to-one reduction in other saving, so there would be no net increase in private saving.

In the other case, the amount that workers will receive (on average) in benefits from traditional Social Security and the personal accounts equals the amount they would have received (on average) from the current system. Note the absence of a benefit increase in this case, meaning that households should not have an interest in reducing other forms of saving. This outcome can be accomplished with a reduction in the overall payroll tax rate, since the private return on personal accounts will likely exceed the return on traditional Social Security contributions. Thus, in this case, the overall payroll tax would be cut. A household that did not plan for retirement would consume the tax cut. Life-cycle households would save a portion of the payroll tax cut. Target savers would spend the entire tax cut.

A related literature describes the impact of tax-based saving incentives such as Individual Retirement Accounts and 401(k) plans on saving (see Engen, Gale, and Scholz 1996; Poterba, Venti, and Wise 1996). The literature has not reached a consensus on the impact of saving incentives on saving, but it does not readily apply to social security plans, which would be mandatory. A key issue in this literature is that participation 
and eligibility for such plans are voluntary and tend to be concentrated in households with a high propensity to save.

Annuitization. Social Security benefits are currently annuitized; this reduces private saving by providing insurance against outliving one's resources. A shift to defined-contribution plans would not inherently require annuitization, although required annuitization would avoid a potential adverse selection problem in private annuity markets caused by the fact that individuals have private information about mortality (Warshawsky 1988). If annuitization were not required, or only partial annuitization were required, the market would still suffer from adverse selection, and households might elect to increase their precautionary saving and effectively self-insure against lifespan uncertainty. This would tend to increase private saving, but would generally make households worse off.

\section{Transition Taxes}

To finance the transition from an unfunded to a fully funded system, either one generation has to pay for the retirement of two generations, or several generations have to share in the costs. Either way, a "tax" is imposed on the affected generations. This tax may take the form of increased tax payments or reduced benefits or both. The structure of this transition tax in turn affects the overall level of saving. Possible transition tax structures include increases in payroll, consumption, or income taxes, or reductions in current or future benefits. The transition can also be financed in the short term with increases in government borrowing, but this merely postpones the payment of the tax; increased debt implies higher future taxes.

The essential issues include which generations bear the burden of the tax and how the tax affects saving and work incentives. The elderly generally have a much higher propensity to consume than younger workers (Gokhale, Kotlikoff, and Sabelhaus 1996). Thus, the greater the extent to which Social Security reform causes the elderly to bear the burden of the transition tax, the more positive the impact on aggregate saving.

For example, cutting current benefits would reduce aggregate consumption more, and thereby give a larger boost to private saving, than raising payroll taxes because the propensity to consume by the elderly is generally higher than that of younger workers. Cutting only future benefits of current workers would have much of the same effect as raising their current payroll taxes: Both would reduce the value of net transfers to that cohort. The smallest impact on saving would occur for an income tax, which would place a larger burden on current workers than on retirees and provide poor incentives for saving. Financing with a con- 
sumption tax would require the elderly to share more of the burden and provide better incentives to save than an income tax would.

The presence of transition taxes implies that the long-run impact could differ greatly from the short- or medium-term impact. The transition to a privatized system may not produce higher national saving. For example, if the government borrows all of the funds needed for transition, national saving could fall and remain below current projections for an extended time. Highlighting the importance of this issue, the transition periods envisioned in most of the proposals are quite lengthy-upwards of 70 years. This period of time is longer than Social Security has been in existence to date.

\section{Means-Testing}

Social Security benefits are adjusted for lifetime and current earnings. A further option is the institution of a means test based on assets or income from assets, including pensions. While the administration of such tests raises several complications, we focus our comments on the impact on saving.

A number of current government programs administer means tests. Empirical evidence from Powers (1994) and Feldstein (1995) and detailed simulations by Hubbard, Skinner, and Zeldes (1995) suggest that assetbased means tests are deleterious to saving. While direct evidence is not available, one could extrapolate that similar effects would occur for Social Security. Indeed, the Petersen (1996) proposal would raise the tax rate on additional saving, which would reduce the incentive to save. However, it would also reduce benefits substantially for upper-income elderly, which might stimulate private saving, and it would reduce government spending and hence raise public saving.

To the extent that means tests based on assets do not reduce saving directly, much of the reason would be due to intergenerational transfers, portfolio shifts, and other strategies to evade the test. An income-based means test would also substantially raise the penalty for working in retirement (Burtless 1996).

\section{Interactions with Private Pensions}

A potentially important but often overlooked factor in reform is the integration of private pension plans with the current Social Security system. Integration occurs when private pension benefits are dependent upon either Social Security benefits or contributions (Merton, Bodie, and Marcus 1987). Currently, about half of all private defined-benefit pension plans are integrated (EBRI 1995). Defined benefit plans are usually integrated on the benefit side. This implies that reductions in Social Security benefits would make the plans less well funded. This should 
cause the plans to have to increase their funding-that is, raise their saving. Thus, the basic thrust of pension integration should be to reduce the negative impact of reform on saving or raise the positive impact. However, if policymakers made very large changes to Social Security benefits-for example, if the program were abolished and replaced with personal accounts-pension plan sponsors might have their legal responsibilities adjusted as well.

\section{Political Economy Issues}

It is crucial to analyze the impact of Social Security reform as it might actually be enacted, as opposed to how it appears on paper. Social Security reform is unlikely to occur in any of the relatively pure forms described by the proposals listed in Table 1. As a reform is enacted, and as a new system evolves, political pressures will flourish; these pressures could in turn influence the impact of reform on saving. We highlight several such issues here; Diamond (1997) provides a much more extensive discussion.

First, to become law, a proposal has to be voted on, and only generations that are alive can vote. Thus, even if a Social Security reform proposal could assure large long-term gains in exchange for relatively small short-term costs, the proposal may not pass because voters may systematically discount the long-term gains, which they will not receive. Any adjustment to accommodate the generations alive at the time of the vote will likely reduce saving by reducing the extent to which the transition costs reduce current consumption.

Second, for a trust fund accumulation to raise national saving, it must not be spent by government on other transfers, government consumption, or tax cuts. The political model underlying congressional behavior is unclear, and there is certainly no guarantee that a surplus can be safely accumulated. Third, if the trust fund invests in private equities, some decision must be made about the trust fund's activities as a corporate owner.

Politically, the advent of personal accounts may make workers more willing to accept the added sacrifice, given that the marginal personal return on such investments is higher than on Social Security contributions. The development of private personal accounts raises a host of other issues, however. Will there be political support to annuitize the balances or will workers want the right to withdraw the funds in a lump sum? Will or should the Congress be able to resist demands to take the accumulated funds out early, say to pay for health expenses, college, or a new business? Similar pressures have repeatedly been faced by the IRA and 401(k) programs. Finally, should market returns plummet for an extended period of time, would political pressure to compensate investors or raise public benefits arise? 


\section{Households' Confidence in Social Security}

One of the ironies of Social Security reform is that placing the system back on track and ensuring workers that benefits, or full benefits, will exist could well reduce private saving. Bernheim (1995), for example, finds a negative correlation between workers' confidence in future benefits and their overall saving.

\section{EVIDENCE From Other COUnTRIES}

Several countries have enacted full or partial privatization plans. In this section, we review evidence from two countries on how these reforms affected national saving.

\section{Chile}

Chile began privatizing its social security system in 1981. Workers were required to contribute 13 percent of their earnings, 10 percent to retirement accounts in registered pension funds and 3 percent to cover the administrative costs of the system. The government regulated the private accounts and provided a minimum guaranteed pension. To recognize previous social security contributions, the government issued bonds to workers as they switched to the new system. Privatization was accompanied by a required 18 percent increase in wages.

The national saving rate was about 12 percent in Chile in the 1970s (Marfan and Bosworth 1994). From 1982 to 1985, the national saving rate fell to 3.6 percent. This decline was due both to government borrowing to finance part of the transition to a privatized system and to a severe recession. From 1986 to 1989, the national saving rate rebounded to an average of 13.6 percent. It then rose to about 18 percent in the 1990-92 period and reached 28 percent in 1995-96.

Several issues arise in understanding both the impact of social security privatization on national saving in Chile, and the implications of those findings for the United States. The direct effect of privatization on national saving can be estimated using various methods. For example, Marfan and Bosworth (1994) show that net saving (that is, contributions plus investment earnings less withdrawals) in private pension funds, which contained the privatized retirement accounts, totaled about 2 percent of GDP in the years 1982 to 1985, 2.6 percent in 1985, and 3.3 percent in the 1990-92 period. These figures represent an upper bound on the direct impact of privatization on national saving: They subtract neither reductions in other private saving resulting from the required 10 percent contributions, nor the increased government borrowing associated with the transition.

Holzmann (1996) estimates the direct effect of privatization on saving as the sum of flow of resources into pensions plus their investment 
earnings, minus the public spending needed to pay off both previously accrued obligations and the cost of compensating workers who switched to private funds. He finds that the direct effect in Chile was negative from 1981 to 1988, peaked at just under 4 percent of GDP in 1990 and hovered between 2 and 3 percent between 1991 and 1995. This estimate overstates the impact of privatization on national saving, however, because it fails to account for possible reductions in other saving. Thus, privatization appears to have contributed directly to only a small portion of the rise in national saving to date.

At least three other factors contributed to the increase in national saving. First, the government undertook a series of economic reforms; this probably raised the growth rate, which in turn would have raised the saving rate. Second, an indirect effect of privatization was to deepen financial markets, which also stimulated growth and thus saving. To the extent that these two factors were important, they would have stimulated saving outside of the retirement accounts. Private, non-pension saving did in fact rise steadily from 2 percent of GDP in 1979-81 to over 9 percent by 1990-92 (Marfan and Bosworth 1994). Third, a significant portion of the increase in national saving was due to increased public saving (Edwards 1996). For these reasons, even advocates of privatization in general and supporters of the Chilean experience in particular are cautious in claiming that privatization significantly influenced national saving in Chile. ${ }^{13}$

Furthermore, privatization would raise saving in the United States to a lesser extent than in Chile, for a number of reasons. First, the role of privatization in deepening financial markets and thus stimulating growth would be much smaller in the United States, which already has the deepest such markets in the world. Second, to the extent that Chilean saving grew due to economic reforms or reduced government spending, the effects on saving occurred independently of privatization and would not be reproduced in the United States. Third, the Chilean social security system contributed net dissaving to government accounts in the prereform period. Annual deficits in social security were financed from general revenues and totaled about 4 percent of GDP (Edwards 1996). In the United States, the Social Security system is currently generating net additions to national saving. Fourth, transition costs-the accumulated benefits earned to date by workers less the accumulated surplus in the social security trust fund-were lower as a percentage of GDP in Chile

${ }^{13}$ Kotlikoff (1996) notes that "Chile's privatization coincided with a spectacular take-off of its economy and has led some observers to suggest that privatizing was the key to Chile's economic growth. The truth here is hard to know. The Chilean economy benefited from a number of concomitant economic reforms. It also benefited from a stable government and from improvements in external economic conditions." Edwards (1996) states that "whether the Chilean reform has actually increased private savings directly is still somewhat of an open question." 
than they would be in the United States. Coverage in the previous Chilean social security system was spotty. The Chilean work force was younger than the American work force, and so had accumulated fewer years of credit. Moreover, benefits had been eroded by inflation. For example, between 1962 and 1980, the average pension paid to a bluecollar worker declined by 41 percent (Edwards 1996). Fifth, the effect of privatization on saving in Chile through the early 1990s is based in part on the pension funds receiving an average annual real return of about 14 percent. Such high returns increase the saving accounted for by pension funds by raising their investment earnings. If the rate of return on privatized contributions were lower in the United States, the impact on saving would be smaller as well.

\section{The United Kingdom}

The United Kingdom has recently moved toward replacing its unfunded public pension at the margin with a pre-funded private alternative. ${ }^{14}$ Britain has a three-tier pension system. The first tier (the basic benefit) is a state-supported minimum annuity payment that is financed out of progressive national insurance contributions made by workers and employers. Basic benefits are about 15 percent of average male earnings and are indexed to the price level, and so are expected to fall to 7 to 8 percent of earnings by 2030. The third tier consists of conventional private pensions and other saving.

The second tier is more complex, consisting of a State EarningsRelated Pension Scheme (SERPS) and private alternatives. In 1978, SERPS was introduced to provide a benefit of one-quarter of average wages in the highest 20 years of earnings, subject to earnings limits. Accrual formulas for SERPS entitlements were cut in 1986 and again in 1995. Combined with the fact that SERPS is indexed to retail prices rather than wages, these cuts suggest a large reduction in replacement ratios in the future.

Most workers, however, have exercised their option to contract out of SERPS, with 50 percent of workers now in occupational pensions (employer-provided defined benefit plans) and an additional 28 percent in private personal pensions (PPPs). When the personal pension option was initiated in 1988, workers were allowed to contract out to an IRA or employer-provided defined contribution plan. The government provided that workers who chose to contract out would have 5.8 percentage points of their national insurance contributions redirected to the private pension. Also, an additional rebate of 2 percent of covered earnings was

\footnotetext{
${ }^{14}$ See Disney and Johnson (1997), Disney and Whitehouse (1992), and Banks, Blundell,
} and Dilnot (1994). 
offered as incentive for those who had not already contracted out. In addition, the rebate was grossed up to take account of the income tax relief on an individual's pension contributions-yielding a total contribution of 8.46 percent of eligible earnings. Given the generosity of the program and the large accompanying volume of advertising, the option turned out to be very popular. ${ }^{15}$ Workers also have the option of contributing additional amounts to their personal pension. Total contribution limits are a function of salary and age and rise from 17.5 percent of covered earnings for those aged 17 to 35 , up to 40 percent for those 61 and over.

It is unclear how personal pensions have affected national saving. Estimates in Disney and Whitehouse (1992) indicate that for about 80 percent of workers, a government contribution of less than 8.46 percent of salary would have been sufficient to induce them to contract out. This suggests that the option created substantial positive income effects that could have raised consumption and thereby reduced private saving.

About 60 percent of workers with PPPs make no contribution to their PPP above the contracted-out rebate, incentive payment, and income tax relief. For this group, current disposable income is the same as if they were still in SERPS, but their wealth is higher. This suggests that, if anything, they would increase their consumption. For the other 40 percent, who do contribute beyond their national insurance payment, some of the extra contribution may be new saving.

As an illustrative calculation, suppose that the 40 percent of workers who contributed additional amounts contributed twice as much as the ones who only contributed their national insurance contribution, and that all of such additional contributions were new saving. Then $2 / 7$ of all contributions to PPPs would represent net additions to national saving. This seems to be an upper bound for the proportion of contributions that would be new saving (under the assumption that workers who contributed above their NIC contributed double what other workers contributed), for three reasons. First, the additional contributions were taxdeductible and thus reduced public saving. Second, all workers may have saved less in other forms because of the income effects of PPPs. Third, workers who contributed more than their national insurance contribution may have financed part or all their additional contributions from existing assets or funds they would have saved anyway. Thus, the net effect on national saving is unclear.

15 The rebate has been cut back and is now structured more generously toward older workers than toward younger workers. 


\section{Recent Studies of the Impact of Social SECURITY REFORM}

Recent estimates have predicted that privatization could produce significant gains in both the capital stock and the economy in the United States. In this section, we review some of these estimates, indicate the source of the gains, and assess the results.

\section{Kotlikoff}

Kotlikoff (1996) uses the Auerbach-Kotlikoff model to examine the impact of social security privatization on the size of the aggregate economy and on economic efficiency. In this model, privatizing social security contributions simply involves setting them equal to zero. Adding a privatized pension system is not necessary: Because households in the model are foresighted and do not face borrowing constraints, they could offset any change in private saving required of them by a mandatory social security system. Privatizing benefits involves phasing them out over time and financing already accrued benefit obligations with a transition tax. The effects of privatization in this model depend largely on (a) the nature of the pre-existing income tax, (b) the perceived tax-benefit linkage in the initial social security system, (c) the type of transition tax employed, and (d) whether the welfare of generations alive at the time of privatization is protected by compensatory policies.

Kotlikoff shows that when the existing income tax is progressive, no tax-benefit linkage exists in the current social security program, consumption taxes finance the transition, and current generations are made no worse off by the reform, privatization leads to a 4.5 percent increase in long-run utility. The capital stock would increase by 6.5 percent after 10 years, 14 percent after 25 years and 21 percent after 150 years. ${ }^{16}$ However, with full benefit-tax linkage in the existing social security program, privatization would cause an efficiency loss of 3.2 percent. (The effects on the capital stock are not reported for this case, but in other simulations, the long-run capital stock typically falls when long-run welfare falls.) Since social security currently provides partial but incomplete linkage, the effects of privatization should lie somewhere between these two sets of results. Kotlikoff also runs a variety of other simulations. In particular, he shows that using debt to finance part of the transition costs will generally reduce the short- and medium-term effects on saving.

These findings raise several issues. First, in the model, the effects of

16 If generations alive at the time of the privatization are not compensated, the capital stock is estimated to grow by 11.5 percent after 10 years, 25 percent after 25 years and 57 percent after 150 years. 
privatization depend sensitively on changes in the perceived tax-benefit linkage in social security. Devine (this volume), however, investigates this issue and finds little evidence that changes in the linkage would induce significant change in labor supply. To the extent that changes in the perceived linkage have limited impact on labor supply, Kotlikoff's model will overstate the positive effects of privatization.

Second, specifications that omit compensation of generations alive at the time of the privatization can generate much higher long-term effects on capital stock. Such specifications are unlikely to be enacted, however, because political constraints on social security reform choices in a democracy dictate that these generations must be compensated for any losses they would incur.

Third, the Auerbach-Kotlikoff model does not include any precautionary motives for saving. Thus, removing the existing social security system from the model generates a large increase in private saving. If households actually have precautionary motives for saving, as in Samwick (1995) or Engen and Gale (1993), then the existence of social security would not have reduced their private saving to such a low level initially. Thus, the absence of precautionary saving against wage risk would tend to overstate the impact of privatization.

\section{Feldstein-Samwick}

Feldstein and Samwick $(1996,1997)$ estimate the effects of financing the currently projected level of future benefits by gradually shifting to a fully funded system of mandatory individual retirement accounts (MIRAs). Under their plan, current retirees would continue to receive PAYGO benefits. Current workers, when they retired, would receive a combination of the PAYGO benefits they had accrued up to the time of the reform and benefits financed from the MIRAs. Eventually, when the generations not yet in the work force at the time of the reform reach retirement age, all retirement benefits would be financed from the MIRAs and the public PAYGO system would therefore be completely phased out. They estimate that financing the MIRAs would require an increase in the combined payroll tax and mandatory saving contribution of about 2 percentage points immediately. This combined rate would decline over time, falling below the current 12.4 percent rate within 20 years and falling to about 2.1 percent after 75 years, when the public system is completely phased out. They estimate that MIRA balances would rise from 25 percent of payroll after 10 years to 82 percent after 25 years and to 230 percent after 75 years. At that point, the balance in MIRAs would roughly equal annual GDP. This would raise the capital stock by 3.7 percent after 10 years, 12 percent after 25 years and 34 percent after 75 years.

There appear to be few channels through which the increase in MIRA balances would be offset by reductions in saving. For example, no change 
would occur in government borrowing. Nor would one expect any substitution with private saving due to change in benefits, because no changes in benefits would be made. The initial increase in the payroll tax would reduce disposable income, which would reduce consumption and private saving, but the payroll tax increase would raise public saving. As long as some of the increased payroll tax causes reduced consumption rather than reduced private saving, the proposal would raise national saving in the short run.

Over the medium and long terms, the value of the MIRA balances will increase and the payroll tax will decline. The first effect would contribute to private saving. The second effect should raise private consumption, and thus reduce private saving. Under the assumptions of the model, the first effect would far outweigh the second effect. These assumptions, however, may be questionable.

A key assumption is that MIRAs would earn a real annual return of 9 percent. Of that total, 3.6 percentage points consists of federal, state, and local income and property taxes, and the remaining 5.4 percentage points are an after-tax return. This figure is based on historical average pre-tax returns in the nonfinancial, corporate sector. However, the estimate is not applicable to MIRAs; specifically, it is too large, for several reasons. First, the pre-tax return in the nonfinancial corporate sector is probably higher than the pre-tax return in other sectors. Market equilibrium should result in the equating of after-tax returns across sectors. Since the nonfinancial corporate sector is probably the most heavily taxed sector in the economy, it will have the highest pre-tax return. Both Bosworth (1996) and Oliner and Sichel (1994) estimate the average pre-tax return to capital in the economy as a whole at 6.2 percent. Since MIRAs will be invested directly in many sectors and will affect the equilibrium return in all sectors, 6.2 percent would be a more appropriate starting point than 9 percent. A second problem is that the return to private investment is risky. The risk-adjusted rate of return, which would be most appropriate, would undoubtedly be lower than 6.2 percent.

A third factor is the presence of administrative costs for private accounts. In Chile, administrative costs are about 15 percent of contributions. Most of these costs are in the nature of fixed costs. MIRA contributions are only expected to be on the order of 2 percent of payroll. Diamond (1997) shows that 45 percent of workers in 1993 had annual earnings under $\$ 13,200$ and another 29 percent had income below $\$ 27,600$. For the three-quarters of workers with income below $\$ 28,000$, MIRA contributions would be less than about $\$ 560$. By comparison, Mitchell (1996) estimates that annual administrative costs would be $\$ 50$ to $\$ 60$ per account per year for a privatized system in the United States. The figure would rise by 10 percent of contributions or $\$ 100$ per participant per year if benefits had to be paid as annuities.

Fourth, the 9 percent estimate represents an average tax rate, rather 
than a marginal one. To the extent that the figure reflects taxation of intramarginal gains - that is, to the extent that economic rents exist- the marginal return should be lower. ${ }^{17}$ These factors imply that the appropriate rate of return on MIRAs is significantly below 9 percent. This in turn would imply lower impacts of social security reform on saving and the capital stock. Feldstein and Samwick set 5.4 percent as a lower bound for the rate of return, but the net return could be significantly lower.

Another set of considerations stem from the fact that the MIRA plan would impose a welfare loss on those members of the current generation of workers who would pay higher payroll taxes during the transition but would not receive higher benefits. This might create a political barrier, which might require an adjustment to garner sufficient political support. This adjustment would undoubtedly soften the transitional costs. This would likely reduce the impact on saving, since the transitional cost of higher payroll taxes is precisely the source of the initial increase in national saving.

\section{CONCLUSION}

Social Security reform offers the potential both to resolve the longterm financial problems facing the program and to exert a positive impact on the national saving rate. But predicting the magnitude of proposed reforms on saving is fraught with difficulty, and even the direction of the change in saving is in doubt under certain circumstances.

Nevertheless, it is clear that improving the funding status of Social Security is necessary to achieve both of these goals, but it is not sufficient. Funding improvements could potentially be offset by increased government spending, lower taxes, or reduced private saving. The nature and magnitude of these responses depend on a variety of issues concerning the behavior of governments, firms, and households, and on specific features of the reform package.

\section{References}

Aaron, Henry J. 1966. “The Social Insurance Paradox.” Canadian Journal of Economics, vol. 32, August, pp. 371-74

Press.

1982. Economic Effects of Social Security. Washington, DC: The Brookings Institution

\footnotetext{
${ }^{17}$ Other criticisms can be raised as well, subject to qualifications. First, the rate of return should fall as the capital stock grows. Second, the 9 percent return only occurs if the government credits the MIRAs with all of the federal, state, and local income and property tax revenue that the added investment generates. This would be hard to accomplish in practice. If this redistribution were not made, the tax receipts would still be present in the economy, but might not serve to raise saving or the capital stock.
} 
Aaron, Henry J., Barry P. Bosworth, and Gary T. Burtless, eds. 1989. Can America Afford to Grow Old? Paying for Social Security. Washington, DC:The Brookings Institution Press.

Abel, Andrew B. 1985. "Precautionary Saving and Accidental Bequests." The American Economic Review, vol. 75(4), September, pp. 777-91.

Advisory Council on Social Security. 1997. Report of the 1994-1996 Advisory Council on Social Security. Washington, DC: U.S. Department of Health and Human Services.

Altonji, Joseph G., Fumio Hayashi, and Laurence J. Kotlikoff. 1992. "Is the Extended Family Altruistically Linked? Direct Tests Using Micro Data." The American Economic Review, vol. 82(5), December, pp. 1177-98.

The 1996 Annual Report of the Board of Trustees of the Federal Old-Age and Survivors Insurance and Disability Insurance Trust Funds, Washington, DC: Government Printing Office, 1996

Auerbach, Alan J. and Laurence J. Kotlikoff. 1983. "An Examination of Empirical Tests of Social Security and Savings." In Helpman, Elhanan, Assaf Razin, and Efrain Sadka, eds., Social Policy Evaluation: An Economic Perspective, pp. 161-79. New York: Academic Press.

. 1987. Dynamic Fiscal Policy. New York: Cambridge University Press.

Avery, Robert B., Gregory E. Elliehausen, and Thomas A. Gustafson. 1986. "Pensions and Social Security in Household Portfolios: Evidence from the 1983 Survey of Consumer Finances." In F. Gerard Adams and Susan M. Wachter, eds., Savings and Capital Formation, pp. 127-60. Lexington, MA: Lexington Books.

Baggette, Jennifer, Robert Y. Shapiro, and Laurence R. Jacobs. 1995. "Social Security —An Update." Public Opinion Quarterly, vol. 59, pp. 420-42.

Banks, James, Richard Blundell, and Andrew Dilnot. 1994. "Tax-Based Saving Incentives in the UK." Mimeo. Paris: OECD.

Barro, Robert J. 1974. "Are Government Bonds Net Wealth?" Journal of Political Economy, vol. 82(6), Nov.-Dec., pp. 1095-1117.

1978. The Impact of Social Security on Private Saving: Evidence from the U.S. Time Series. Washington, DC: American Enterprise Institute for Public Policy Research.

. 1989. "The Ricardian Approach to Budget Deficits." Journal of Economic Perspectives, vol. 3(2), Spring, pp. 37-54

Bernheim, B. Douglas. 1987a. "The Economic Effects of Social Security: Towards a Reconciliation of Theory and Measurement." Journal of Public Economics, vol. 33, pp. 273-304. . 1987b. "Ricardian Equivalence: An Evaluation of Theory and Evidence." In Fischer, Stanley, ed., NBER Macroeconomics Annual: 1987, Volume 2, pp. 263-304. Cambridge, MA: The MIT Press.

1989. "A Neoclassical Perspective on Budget Deficits." Journal of Economic Perspectives, vol. 3, pp. 55-72.

. 1995. "Do Households Appreciate Their Financial Vulnerabilities? An Analysis of Actions, Perceptions, and Public Policy." In American Council for Capital Formation, Tax Policy and Economic Growth, pp. 1-30. Washington, DC: ACCF.

1997. "Rethinking Saving Incentives." In Auerbach, Alan J., ed., Fiscal Policy: Lessons from Economic Research, pp. 259-312. Cambridge, MA: The MIT Press.

Bernheim, B. Douglas and John Karl Scholz. 1993. "Private Saving and Public Policy." In James M. Poterba, ed., Tax Policy and the Economy, Volume 7, pp. 73-110. Cambridge, MA: The MIT Press.

Bipartisan Commission on Entitlement and Tax Reform. 1995. Final Report to the President, January.

Blinder, Alan S., Roger H. Gordon, and Donald E. Wise. 1981. "Rhetoric and Reality in Social Security Analysis: A Rejoinder [Reconsidering the Work Disincentive Effects of Social Security]." National Tax Journal, vol. 34(4), December, pp. 473-78.

Bosworth, Barry P. 1996. "Fund Accumulation: How Much? How Managed?" In Diamond, Peter A., David C. Lindeman, and Howard Young, eds., Social Security: What Role for the Future? pp. 89-115. Washington, DC: National Academy of Social Insurance.

Burtless, Gary. 1996. "The Folly of Means-Testing Social Security." In Diamond, Peter A., David C. Lindeman, and Howard Young, eds., Social Security: What Role for the Future? pp. 172-80. Washington, DC: National Academy of Social Insurance.

Committee for Economic Development. 1997. Fixing Social Security. New York: CED

Devine, Theresa J. 1996. "Demographics, Social Security Reform, and Labor Supply." This volume. 
Diamond, Peter A. 1965. "National Debt in a Neoclassical Growth Model." The American Economic Review, vol. 55, December, pp. 1126-50.

1977. "A Framework for Social Security Analysis." Journal of Public Economics, vol. 8(3), December, pp. 275-98.

1997. "Macroeconomic Aspects of Social Security Reform." Brookings Papers on Economic Activity, 2, forthcoming.

Diamond, Peter A. and Jerry A. Hausman. 1984. "Individual Retirement and Savings Behavior." Journal of Public Economics, vol. 23, February/March, pp. 81-114.

Dicks-Mireaux, Louis and Mervyn King. 1984. "Pension Wealth and Household Savings: Tests of Robustness." Journal of Public Economics, vol. 23, pp. 115-39.

Disney, Richard and Paul Johnson. 1997. "The United Kingdom: A Working System of Minimum Pensions?" Mimeo, Institute for Fiscal Studies.

Disney, Richard and Edward Whitehouse. 1992. The Personal Pensions Stampede. London: Institute for Fiscal Studies.

Dynan, Karen E., Jonathan Skinner, and Stephen P. Zeldes. 1997. "Do the Rich Save More?" Mimeo.

Edwards, Sebastian. 1996. "The Chilean Pension Reform: A Pioneering Program." NBER Working Paper no. 5811, November.

Employee Benefit Research Institute. 1995. EBRI Databook on Employee Benefits. Washington, DC.

Engen, Eric M. and William G. Gale. 1993. “IRAs and Saving in a Stochastic Life Cycle Model." Mimeo, April.

1997. "Debt, Taxes, and the Effects of 401(k) Plans on Household Wealth Accumulation." May.

Engen, Eric M., William G. Gale, and John Karl Scholz. 1996. "The Illusory Effect of Saving Incentives on Saving." Journal of Economic Perspectives, vol. 10(4), pp. 113-38.

Feldstein, Martin. 1974. "Social Security, Induced Retirement, and Aggregate Capital Accumulation." Journal of Political Economy, vol. 82(5), September/October, pp. 905-926 . 1982. "Social Security and Private Saving: Reply." Journal of Political Economy, vol. 90(3), June, pp. 630-42.

1995. "College Scholarship Rules and Private Saving." The American Economic Review, vol. 85(3), June, pp. 552-66.

. 1996. "Social Security and Saving: New Time Series Evidence." National Tax Journal, vol. 49(2), June, pp. 151-64.

Feldstein, Martin and Anthony Pellechio. 1979. "Social Security and Household Wealth Accumulation: New Microeconometric Evidence." The Review of Economics and Statistics, 61(3), August, pp. 361-68.

Feldstein, Martin and Andrew Samwick. 1992. "Social Security Rules and Marginal Tax Rates." National Tax Journal, vol. 45(1), March, pp. 1-22.

1996. "The Transition Path in Privatizing Social Security." NBER Working Paper no. 5761, September.

. 1997. "The Economics of Prefunding Social Security and Medicare Benefits." NBER Working Paper no. 6055, June.

Gale, William G. 1995. "The Effects of Pensions on Wealth: A Re-evaluation of Theory and Evidence." The Brookings Institution, June 5.

Gokhale, Jagadeesh, Laurence J. Kotlikoff, and John Sabelhaus. 1996. "Understanding the Postwar Decline in U.S. Saving: A Cohort Analysis." Brookings Papers on Economic Activity 1, pp. 315-90.

Holzmann, Robert. 1996. "Pension Reform, Financial Market Development, and Economic Growth: Preliminary Evidence from Chile." International Monetary Fund Working Paper, August.

Hubbard, R. Glenn. 1986. "Pension Wealth and Individual Saving." Journal of Money, Credit and Banking, vol. 18(2), May, pp. 167-78.

. 1987. “Uncertain Lifetimes, Pensions, and Individual Saving." In Bodie, Zvi, John B. Shoven, and David A. Wise, eds., Issues in Pension Economics, pp. 175-210. Chicago, IL: University of Chicago Press.

Hubbard, R. Glenn and Kenneth L. Judd. 1986. "Liquidity Constraints, Fiscal Policy, and Consumption." Brookings Papers on Economic Activity, 1, pp. 1-50. . 1987. "Social Security and Individual Welfare: Precautionary Saving, Borrowing 
Constraints, and the Payroll Tax." The American Economic Review, vol. 77(4), September, pp. 630-46.

Hubbard, R. Glenn, Jonathan Skinner, and Stephen P. Zeldes. 1995. "Precautionary Saving and Social Insurance." Journal of Political Economy, vol. 103(2), April, pp. 360-99.

Katona, George. 1965. Private Pensions and Individual Saving. University of Michigan Press.

Kennickell, Arthur B., Martha Starr-McCluer, and Annika E. Sunden. 1997. "Family Finances in the U.S.: Recent Evidence from the Survey of Consumer Finances." Federal Reserve Bulletin, vol. 83, pp. 1-24.

Kotlikoff, Laurence J. 1979a. "Social Security and Equilibrium Capital Intensity." Quarterly Journal of Economics, vol. 93(2), May, pp. 233-53.

.1979b. "Testing the Theory of Social Security and Life Cycle Accumulation." The American Economic Review, vol. 69(3), June, pp. 396-410.

. 1987. "Justifying Public Provision of Social Security." Journal of Policy Analysis and Management, vol. 6(4), Summer, pp. 674-89.

. 1996. "Privatizing School Security at Home and Abroad." The American Economic Review, vol. 86(2), pp. 368-72.

Kotlikoff, Laurence J. and Jeffrey Sachs. 1997. "It's High Time to Privatize." Brookings Review, vol.15(3), Summer, pp. 16-22.

Kotlikoff, Laurence J., John B. Shoven, and Avia Spivak. 1987. “Annuity Markets, Savings, and the Capital Stock." In Bodie, Zvi, John B. Shoven, and David A. Wise, eds., Issues in Pension Economics, pp. 211-34. Chicago, IL: University of Chicago Press.

Laibson, David. 1996. "Hyperbolic Discounting Functions, Undersaving, and Savings Policy." NBER Working Paper no. 5635.

Leimer, Dean R. and Selig D. Lesnoy. 1982. "Social Security and Private Saving: New Time-Series Evidence." Journal of Political Economy, vol. 90(3), June, pp. 606-629.

Leimer, Dean R. and David H. Richardson. 1992. "Social Security, Uncertainty Adjustments and the Consumption Decision." Economica, vol. 59(235), August, pp. 311-35.

Lucas, Robert E., Jr. 1976. "Econometric Policy Evaluation: A Critique." In CarnegieRochester Conference Series, The Phillips Curve, pp. 19-46.Amsterdam: North-Holland.

Marfan, Manuel and Barry P. Bosworth. 1994. "Saving, Investment, and Economic Growth." In Bosworth, Barry P., Rudiger Dornbusch, and Raul Laban, eds., The Chilean Economy: Policy Lessons and Challenges, pp. 165-200. Washington, DC: The Brookings Institution.

Merton, Robert C. 1983. "On the Role of Social Security as a Means for Efficient Risk Sharing in an Economy Where Human Capital Is Not Tradeable." In Bodie, Zvi and John B. Shoven, eds., Financial Aspects of the United States Pension System, pp. 325-58. Chicago, IL: University of Chicago Press.

Merton, Robert C., Zvi Bodie, and Alan J. Marcus. 1987. "Pension Plan Integration as Insurance Against Social Security Risk." In Bodie, Zvi, John B. Shoven, and David A. Wise, eds., Issues in Pension Economics, pp. 147-69. Chicago, IL: University of Chicago Press.

Mitchell, Olivia S. 1996. "Administrative Costs in Public and Private Retirement Systems." NBER Working Paper no. 5734, August.

Mitchell, Olivia S. and Stephen P. Zeldes. 1996. "Social Security Privatization: A Structure for Analysis." The American Economic Review Papers \& Proceedings, vol. 86, no. 2 (March), pp. 363-67.

Munnell, Alicia H. 1974. "The Impact of Social Security on Personal Savings." National Tax Journal, vol. 27(4), December, pp. 553-67.

Oliner, Stephen D. and Daniel Sichel. 1994. "Computers and Output Growth Revisited: How Big Is the Puzzle?" Brookings Papers on Economic Activity, 2, pp. 274-334.

Petersen, Peter G. 1996. Will America Grow Up Before It Grows Old? New York: Random House.

Poterba, James M., Steven F. Venti, and David A. Wise. 1996. "How Retirement Programs Increase Savings." Journal of Economic Perspectives, vol. 10(4), pp. 91-112.

Powers, Elizabeth T.1994. "Does Means Testing Welfare Discourage Saving? Evidence from the National Longitudinal Survey of Women." Federal Reserve Bank of Cleveland, March.

Samuelson, Paul A. 1958. "An Exact Consumption-Loan Model of Interest With or Without the Social Contrivance of Money." Journal of Public Economics, vol. 66, December, pp. 467-82. 
Samwick, Andrew A. 1995. "The Limited Offset Between Pension Wealth and Other Private Wealth: Implications of Buffer-Stock Saving." Mimeo.

Seater, John J. 1993. "Ricardian Equivalence." Journal of Economic Literature, vol. 31(1), March, pp. 142-90.

Thaler, Richard H. 1994. "Psychology and Savings Policies." The American Economic Review, vol. 84(2), May, pp. 186-92.

Turner, John A. 1997. "Economic Analysis of Mandatory Defined Contribution Pension Systems." International Labor Office, September 8.

Warshawsky, Mark. 1988. "Private Annuity Markets in the US: 1919-1984." Journal of Risk and Insurance, vol. 55(3), September, pp. 518-28. 


\section{Discussion}

\section{James M. Poterba*}

Raising national saving is one of the primary reasons that many potential reformers offer for changing the current Social Security system. In this paper, Eric Engen and William Gale summarize what we know about how the existing Social Security system affects national saving. They present a valuable discussion more generally of the impact of Social Security in a variety of theoretical models of household saving. They also venture into the more difficult business of describing how potential Social Security reforms might affect personal and national saving. ${ }^{1}$

The saving effects of Social Security reform depend, at least to some degree, on the reasons households save. A mini-revolution has occurred over the past decade in the economic analysis of personal saving. Most of the latest work on this issue explores models of precautionary saving, in which households save in part to finance their retirement, but also to build a financial cushion that they can rely on in the event of adverse income shocks. Engen and Gale devote a substantial part of their paper to analyzing how Social Security reforms might change the risks borne by households and to describing how such changes might affect precautionary saving. These effects are complex, and the authors rightly conclude that the effect of Social Security reform on precautionary saving is likely to depend on the detailed provisions of the reform proposals. Moreover, they note that we do not have sufficiently precise parameter estimates to draw strong conclusions about some of these effects.

Replacing the current unfunded defined-benefit Social Security system with a fully funded defined-contribution system, as some of the most

\footnotetext{
*Mitsui Professor of Economics, Massachusetts Institute of Technology.
}

${ }^{1}$ Parts of this comment draw heavily on Poterba (1996). 
aggressive reform proposals suggest, would have risk-shifting effects. These changes might affect household saving through precautionary saving channels, and some of these effects might blunt the direct (and positive) saving effect of a shift to a fully funded system. While recognizing these effects, one must not forget that there is substantial agreement, although not unanimity, within the economics profession that an increase in Social Security funding would raise government saving and thereby increase national saving.

Some reform proposals mandate higher private saving while others call for higher taxes and higher government saving. For the latter proposals, a key question is whether higher Social Security taxes relative to current benefit outflows would lead to larger deficits elsewhere in the federal budget. While one can speculate on the political economy of deficit determination, at least in the current climate of fiscal stringency, large expansions in the non-Social Security deficit seem unlikely.

With respect to the effect of higher government saving on national saving, there is more controversy, but the balance of evidence still supports a substantial effect. The extent to which national saving rises when government saving rises depends on the degree to which households internalize the government's budget constraint and reduce private saving to offset higher government saving. This is the "Ricardian equivalence" debate. Barro (1974) argues that operative intergenerational links exist that make such offsets possible. Most of the empirical evidence on the nature of such links, summarized and extended, for example, in Altonji, Hayashi, and Kotlikoff (1992), suggests that intergenerational altruism cannot fully explain observed patterns in intergenerational transfers.

More generally, a significant literature on the link between government deficits and personal saving raises questions about the predictive content of Barro's model. Bernheim (1987a) provides a somewhat dated but very helpful survey of this literature. Thus, it seems likely that a Social Security reform that replaces the current underfunded definedbenefit system with either a fully funded defined-benefit system or a fully funded defined-contribution system is likely to raise national saving.

While there is broad agreement that a shift to a fully funded system will raise the national saving rate, the precise magnitude of this effect is difficult to judge, and the authors do a first-rate job of explaining the reasons for these difficulties. This lack of agreement is also reflected in disagreement about the effect of the current Social Security system on private saving. In a recent survey of public finance economists at leading research universities, Fuchs, Krueger, and I (1997) asked respondents what they thought the U.S. personal saving rate would be today if the Social Security program had never been enacted. The median respondent indicated that the personal saving rate, saving divided by disposable income, would have been 3 percentage points higher than its current level 
of 5 percent. The responses showed substantial dispersion. The 25th percentile respondent indicated that Social Security had reduced personal saving by only 1 percent of disposable income, while the 75th percentile respondent suggested a decline of 5 percentage points.

The lack of consensus on the precise amount by which the current Social Security system has reduced private saving is not a surprise. No definitive empirical tests are available for resolving this issue, and households may modify their behavior, and therefore their saving, in many ways in response to the Social Security system. Some of the uncertainties in evaluating the effect of Social Security on private saving include whether or not households correctly perceive the future value of their benefits, how retirement decisions are affected by Social Security, and whether individuals have operative bequest motives that link their utility to that of their children, who will be called upon to finance Social Security payouts.

The existing empirical literature on Social Security and saving can be divided into two waves. The first involved time series estimates of how aggregate consumption responded to changes in the value of aggregate Social Security wealth. Studies in this vein include Barro (1978), Feldstein (1974, 1982), Leimer and Lesnoy (1982), and Munnell (1974). It is extremely difficult to disentangle the effects of Social Security wealth, a time series with a strong trend, from other trending variables and other shocks in a relatively short time series. Auerbach and Kotlikoff (1983) present simulation evidence showing that reduced-form equations relating aggregate consumption to aggregate income, wealth, and Social Security wealth are extremely sensitive to specification changes and to other factors in the economic environment. As the limited robustness of these results has become recognized, the findings of these studies have probably been down-weighted by many policy analysts.

A second wave of research used household-level data to explore the degree of offset between Social Security wealth and other private wealth. Examples include Feldstein and Pellechio (1979), Blinder, Gordon, and Wise (1981); Hubbard (1986), and Bernheim (1987b). The point estimates of the degree of offset vary substantially across studies. More generally, this literature suffers from a difficult problem of identification. The cross-sectional variation in Social Security wealth stems largely from differences in lifetime income, since benefit formulas are tied to an individual's earnings history. Lifetime income may be correlated with an individual's saving propensity in a variety of ways, so it is difficult to isolate the effect of Social Security wealth on non-Social Security wealth accumulation. Moreover, since all households of a given age face the same Social Security benefit schedule, it is not possible to compare otherwise identical households who face different benefits.

The identification problems that arise in measuring how the current Social Security system affects private saving are deep, and they are 
unlikely to be resolved in the future. In the absence of definitive econometric evidence on the saving effect of the current Social Security system, many economists probably rely on relatively simple models in assessing the effects of the program. If Social Security benefits were lower, those households that behave as "life-cycle consumers" would accumulate more assets early in life, so that they would be able to finance their retirement consumption. The key uncertainty is how large an effect this would be, and it depends in part on the degree to which the life-cycle model describes consumer behavior. This is where the recent outpouring of research on models of personal saving behavior enters the discussion.

One of the key stylized facts about saving in the U.S. economy is that a substantial fraction of households reach retirement age with very low levels of financial assets, in contrast to the predictions of the simplest life cycle models. For example, Poterba, Venti, and Wise (1994) report that in 1991, the median level of financial assets for households aged 65 to 69 was only $\$ 14,000$. Such households have limited scope to reduce private saving in response to higher government saving, hence the earlier conclusion that higher government saving through the Social Security system would raise national saving.

The low level of financial assets at retirement age also raises questions about how households determine their saving patterns and, in particular, whether they exhibit forward-looking behavior in planning their lifetime consumption pattern. Myopia, a failure to think about retirement when workers are still in the labor force, is one explanation for the low level of assets for many households. If this is the correct explanation, then it seems unlikely that higher government saving through the Social Security system would produce an offsetting decline in private saving: Myopic households are not thinking about their future needs.

A related question concerns the degree to which households perceive the future actual impact of the Social Security system on their economic status in retirement. Many households in the baby-boom generation have little confidence in the future of the Social Security system, so they may already be saving for their retirements. Bernheim (1995) presents survey evidence suggesting that those households with the least confidence in the future of the system exhibit the highest personal saving rates. This suggests that in describing the effect of Social Security reform on saving patterns, it may be important to consider household perceptions as well as actual programmatic changes.

One of the most interesting parts of Engen and Gale's paper is its discussion of how specific provisions in different Social Security reform proposals might affect private saving. For example, they briefly discuss reforms that would means-test Social Security benefits in some fashion, presumably with a rule that would reduce payouts to households with income and/or assets above a certain level. Analyzing the potential 
saving effect of means-testing Social Security benefits is difficult, because the United States has never tried such a program. Yet experience from another type of means-tested program, college financial aid, may provide some guidance in thinking about this proposal.

Means-tested Social Security benefits would alter the rate of return to asset accumulation, just as means-tested scholarship programs alter the rate of return to households with pre-college age children. Feldstein (1995) uses data from the Survey of Consumer Finances to suggest that households that face high educational tax rates tend to have lower levels of accumulated wealth than those with lower implicit tax rates. Kim (1997) presents related evidence from the Survey of Income and Program Participation. Both of these studies suggest that a significant fraction of households exhibit substantial foresight in considering how their saving decisions will affect their future benefits, and that they adjust their behavior in response to these incentives. Edlin (1993) speculates that the currently observed behavior is an underestimate of the potential effect of means-testing rules of this form, because many parents with children currently approaching college age were not aware of the nature of these rules.

These results stand in sharp contrast to the foregoing discussion of myopia and the problem of explaining why some households accumulate virtually no assets. The reconciliation of these two strands of analysis involves heterogeneity in household attributes and behavior. At least some households are thinking about long-term issues in financial planning, and they are modifying their levels of saving and their portfolio allocations in light of the implied returns to different activities. Others are not so farsighted, and their saving may not alter very much in response to changes in the Social Security program. Measuring and modeling such household heterogeneity is likely to be a critical aspect of any attempt to describe either how Social Security reform will affect aggregate saving or how it will affect the distribution of retirement resources across households.

\section{References}

Altonji, Joseph G., Fumio Hayashi, and Laurence J. Kotlikoff. 1992. "Is the Extended Family Altruistically Linked? Direct Tests Using Micro Data." The American Economic Review, vol. 82, pp. 1177-98.

Auerbach, Alan J. and Laurence J. Kotlikoff. 1983. “An Examination of Empirical Tests of Social Security and Savings." In E. Helpman, ed., Social Policy Evaluation: An Economic Perspective, pp. 161-74. New York: Academic Press.

Barro, Robert J. 1974. "Are Government Bonds Net Worth?" Journal of Political Economy, vol. 82, pp. 1095-1118.

. 1978. The Impact of Social Security on Private Saving: Evidence from the United States Time Series. Washington, DC: American Enterprise Institute.

Bernheim, B. Douglas. 1987a. "Ricardian Equivalence: An Evaluation of Theory and Evidence." In S. Fischer, ed., NBER Macroeconomics Annual: 1987, pp. 263-304. Cambridge, MA: The MIT Press. 
1987b. "The Economic Effects of Social Security: Toward a Reconciliation of Theory and Evidence." Journal of Public Economics, vol. 33, pp. 273-304.

. 1995. "Do Households Appreciate Their Financial Vulnerabilities? An Analysis of Actions, Perceptions, and Public Policy." In American Council for Capital Formation, Tax Policy and Economic Growth, pp. 1-30. Washington, DC: ACCF.

Blinder, Alan S., Roger H. Gordon, and David E. Wise. 1981. "Social Security, Bequests, and the Life Cycle Theory of Saving: Cross-Sectional Tests." In F. Modigliani and R. Hemming, eds., The Determinants of National Saving and Wealth, pp. 89-122. New York: St. Martin's Press.

Edlin, Aaron S. 1993. "Is College Financial Aid Equitable and Efficient?" Journal of Economic Perspectives, vol. 7, pp. 143-58.

Feldstein, Martin S. 1974. "Social Security, Induced Retirement, and Aggregate Capital Accumulation." Journal of Political Economy, vol. 82, September/October, pp. 905-26.

- 1982. "Social Security and Private Saving: Reply." Journal of Political Economy, vol. 90, pp. 630-41.

. 1995. "College Scholarship Rules and Private Saving." The American Economic Review, vol. 85, pp. 552-66.

Feldstein, Martin S. and Anthony Pellechio. 1979. "Social Security and Household Wealth Accumulation: New Microeconometric Evidence." The Review of Economics and Statistics, vol. 61, no. 3, pp. 361-68.

Fuchs, Victor, Alan Krueger, and James Poterba. 1997. "Empirical Research, Values, and Economic Policy." Mimeo, Stanford University Department of Economics.

Hubbard, R. Glenn. 1986. "Pension Wealth and Individual Saving." Journal of Money, Credit and Banking, vol. 18, pp. 167-78.

Kim, Taejong. 1997. "Implicit Taxes in College Financial Aid and Family Saving." Mimeo, University of Toronto Department of Economics.

Leimer, D. and S. Lesnoy. 1982. "Social Security and Private Saving: New Time-Series Evidence." Journal of Political Economy, vol. 90, pp. 606-629.

Munnell, Alicia. 1974. The Effect of Social Security on Personal Savings. Cambridge, MA: Ballinger.

Poterba, James M. 1996. "Personal Saving Behavior and Retirement Income Modelling: A Research Assessment." In Eric Hanushek and Nancy Maritato, eds., Assessing Knowledge of Retirement Behavior, pp. 123-49. Washington, DC: National Academy Press.

Poterba, James M., Steven F. Venti, and David Wise. 1994. "Targeted Retirement Saving and the Net Worth of Elderly Americans." The American Economic Review, vol. 84 (May), pp. 180-85. 


\section{DiscusSION}

\section{Andrew A. Samwick*}

Once again, the Social Security program in the United States is projected to be in deficit in the near future, and proposals for reform are everywhere. The history of this treasured government program contains many instances in which the benefit formulas and contribution rates were changed, sometimes to ensure its solvency and other times to promote fairness. What is substantively new about the current proposals from the Advisory Council and others is that some of them strongly advocate more fundamental change in the system's structure. These so-called privatizations would involve not just the prefunding of future liabilities to an extent unprecedented in the pay-as-you-go system but the devolution of management responsibilities for the funds to individualized accounts.

While the catalysts for reform are clearly the adverse trends in the basic demographics of mortality and fertility rates, the primary reason cited for the privatization schemes is that they would boost the national saving rate, which has declined substantially over the past two decades. The present contribution by Eric Engen and William Gale is noteworthy as a clear discussion of the key issues for analyzing the impact of Social Security reform on saving. In particular, it gives an appropriate treatment of capital market imperfections against the backdrop of a life-cycle model of consumption. My remarks will simply extend some of their most important arguments.

The most important topic addressed in the Engen and Gale paper is that raising the saving rate does not necessarily imply an increase in the welfare of households. In an economy with no taxes or other market imperfections, the saving rate reflects nothing more than the desire of

*Assistant Professor, Department of Economics, Dartmouth College. 
households to smooth their consumption over their life cycles. If a tax is placed on the return to saving-such as a capital income tax-then the saving rate will fall as lifetime consumption decisions are distorted. In that case, it may be possible to raise welfare by choosing an alternative tax base and thereby allowing the saving rate to increase.

In an economy with not just taxes but also other market imperfections, households might save to overcome those imperfections, regardless of the tax distortions on intertemporal substitution of consumption. For example, if private annuity markets are not actuarially fair, then households will inefficiently save too much relative to a case in which such markets were actuarially fair. Another imperfection is the inability of households to borrow against their future earnings. Households that anticipate increasing income levels might like to borrow against that income to finance current consumption. Since broad markets for borrowing against future income do not exist, households will care not only about the present value of their lifetime earnings but the timing of their earnings over their life cycle. They will be saving too much while young. A third imperfection is that future earnings are uncertain, and few if any markets allow households to obtain insurance against bad income shocks. As a result, households will increase their savings to buffer their future consumption against unusually low income.

Although it is commonly discussed only in terms of the life-cycle motive for saving, Social Security affects all of these margins. Benefits are paid as an indexed annuity that is not already available in private markets. Social Security imposes high effective taxes on young households who may already be liquidity constrained. Benefits are also a progressive function of a long average of earnings, providing some insurance against bad income shocks over a lifetime. The key feature that makes the existing market imperfect is typically some source of uncertaintywhether in the length of life, disability, or earnings capacity. A long literature in economics considers the way adverse selection and moral hazardproblems of hidden information or hidden action-may cause markets to be inefficient. Because Social Security provides social insurance against many risks, simply noting that other personal saving was reduced after Social Security was introduced, or that it is likely to increase under a privatization, is an incomplete if not misleading way to conduct welfare analysis.

Privatization of Social Security has been discussed in the context of many different proposals, each with different combinations of benefit reductions, payroll taxes, and sometimes other fiscal policy changes as well. When thinking about the saving or welfare effects of a privatization, it is important to recognize that the main requirement for a privatization is the prefunding of the liabilities of the current (and future) generations of workers. Accumulating a dedicated capital stock to finance future benefits payments is a precondition for any privatization.

It is precisely the inevitability of one generation of workers paying 
for two generations' retirement benefits that prevents an easy transition from a pay-as-you-go system to a funded system. What is not often realized is that this does not necessitate a doubling of the current payroll tax. The pay-as-you-go benefits of the current generation of retirees must be purchased at the tax rates given by the current system. The benefits of future generations can be purchased at the rate of return on capital, which is much higher than the implied rates of return on the pay-as-you-go system. The most important question is therefore how high the transition tax must be to prefund future generations' benefits.

In some recent work with Martin Feldstein, we estimated the additional tax required to prefund the liabilities of the current generation of workers with no existing liabilities from the old system (Feldstein and Samwick 1997). Assuming that contributions would earn the historical pre-tax rate of return on the corporate sector (about 9 percent), only 2 percent of covered payroll would be required. If the government could not (or chose not to) rebate the 40 percent of this return that is collected in taxes on corporations, then contributions of 5.7 percent would be required.

In the context of the current plight of Social Security, these numbers are quite astounding. The most recent Trustees' Report lists the current fiscal imbalance in the pay-as-you-go system at 2.23 percent of covered payroll. If nothing were done about this long-term deficit until the trust fund is exhausted in 2030, an additional tax of about 6 percent of covered payroll would have to be levied just to maintain the solvency of the pay-as-you-go system. Given the taxes that will inevitably have to be raised under the old system, privatization is simply not that expensive. And the true payoff to privatizing appears at roughly the end of the 75-year horizon used for forecasting, when the last of the beneficiaries of the old system have passed away and taken the current pay-as-you-go tax with them.

Obviously this type of analysis has complications, but none of them pose an insurmountable obstacle to reform. For example, the current generation of workers will pay higher taxes for the same benefits and will therefore be worse off. However, their children's generation will be better off by roughly the same amount, so even minor additions to intergenerational transfers from the children to the parents could alleviate some of this burden. The rewards of prefunding are not so distant that such links are tenuous. The current system also offers insurance against capital market risk and lifetime poverty. In our analysis, we showed that prefunding reasonable amounts of insurance against both contingencies is not particularly expensive. Finally, once a capital stock that is roughly the magnitude of GDP is accumulated in dedicated retirement accounts, the responsibility for managing the accounts should be divested from the government to private organizations. Although the precise details of this management structure are left to be determined, a system that resembled passively managed, broadbased mutual funds would likely not be too costly.

One shortcoming of the Engen-Gale paper is that it does not make a 
clear estimate of the extent to which national saving will increase as a result of a privatization. Since the essential part of a privatization is the tax increase required to fund future benefits, saving during the transition must be higher. With future benefits unchanged, the transition involves only an increase in taxes. The extent to which private saving is reduced in response is no different than in response to any other tax increase. Households that are not liquidity-constrained may choose to smooth their increased tax burdens to future years and therefore save less than they currently are. Households that are already liquidity-constrained will not be able to save less, and those that are saving primarily for precautionary reasons will not change their behavior at all. The impact of the transition on national saving will therefore be on the order of magnitude of the tax increase that is imposed.

It may be possible to structure a transition that achieves a bit more in terms of welfare if policymakers are willing to give up a bit of national saving. In some recent work, I have investigated the possibility of making a household's participation in a new system voluntary in a way that is similar to the system of "contracting-out" in the United Kingdom (Samwick 1997). By allowing participation to be voluntary, we can be sure that the first-order effect of the reform is to make households that do enter the reform better off. The main result of that work thus far is that the heterogeneity in people's tastes for saving is critical to the success of any voluntary reform. Achieving the twin goals of high voluntary participation and maintenance of the national saving rate will in general require multiple reform options along the lines of an optimal income tax.

In conclusion, the most important lesson to emerge from the work by Engen and Gale is that in a developed economy such as the United States, policymakers should be focusing on welfare, not saving. When discussing reforms to the social insurance system, the two concepts are simply not equivalent. An obvious way to improve welfare is to remove the burden of the pay-as-you-go financing of Social Security from future generations. The projected tax rate of about 18 percent of covered payroll is not a particularly generous bequest for future generations. When discussing privatizations of Social Security that might achieve that end, it is also important to recognize that the important element of reform is the prefunding of new liabilities that would otherwise be incurred. The saving effects of that tax increase are fairly straightforward. When the reform proposal includes not just a privatization but a change in the promised benefit amounts, then saving effects become more ambiguous.

\section{References}

Feldstein, Martin S. and Andrew A. Samwick. 1997. "The Economics of Prefunding Social Security and Medicare Benefits." Forthcoming in B. Bernanke and J. Rotemberg, eds., Macroeconomics Annual 1997. Cambridge, MA: National Bureau of Economic Research.

Samwick, Andrew A. 1997. "Discount Rate Heterogeneity and Social Security Reform." Manuscript, Dartmouth College, May. 